\title{
Macrozooplankton community patterns driven by water circulation in the St. Lawrence marine system, Canada
}

\author{
Aurélie Descroix ${ }^{1}$, Michel Harvey ${ }^{2, *}$, Suzanne Roy ${ }^{1}$, Peter S. Galbraith ${ }^{2}$ \\ ${ }^{1}$ Institut des Sciences de la Mer (ISMER), Université du Québec à Rimouski (UQAR), 310 Allée des Ursulines, Rimouski, \\ Québec, G5L 3A1, Canada \\ ${ }^{2}$ Direction des Sciences Océaniques, Ministère des Pêches et des Océans, Institut Maurice-Lamontagne, CP 1000, Mont-Joli, \\ Québec, G5H 3Z4, Canada
}

\begin{abstract}
Six cruises were carried out in the lower St. Lawrence Estuary (LSLE) and the NW Gulf of St. Lawrence (NW GSL) in spring and fall 1998, 2000, and 2001 to study the species composition, abundance, and distribution of macrozooplankton in relation to the physical environment. Our results confirm that the LSLE and the NW GSL represent 2 different physical environments. These differences are likely due to different circulation patterns observed between the 2 regions: the estuarine circulation in the LSLE and a quasi-permanent cyclonic gyre in the NW GSL. The dominant species found in both environments (LSLE and NW GSL) is the mysid Boreomysis arctica, but we observed no significant regional and interannual variations in its abundance. In contrast, 2 distinct groups characterized the LSLE and the NW GSL when we examined the other macrozooplankton groups. Two euphausiid species, Meganyctiphanes norvegica and Thysanoessa raschii, dominated in the LSLE. Their abundances were 6 and 15 times higher in the LSLE than in the NW GSL, respectively. On the other hand, the NW GSL was dominated by chaetognaths, hyperiid amphipods, and siphonophores. These groups were twice as abundant in the NW GSL as in the LSLE. Such interregional variations were attributed to different circulation patterns and different trophic systems. Furthermore, important interannual variations in the abundance of the major macrozooplankton species were also observed between 1998 and 2001 in the LSLE and the NW GSL. In the NW GSL, the arctic and boreo-arctic species were more abundant in 1998 than in 2000 and 2001. In contrast, their abundance was lowest in 1998, and highest in 2000 and 2001 in the LSLE. We hypothesize that stronger inflow of Labrador Shelf waters in the GSL via the Strait of Belle Isle may increase the advection of macrozooplankton into the LSLE.
\end{abstract}

KEY WORDS: Macrozooplankton - Gulf of St. Lawrence $\cdot$ Cold intermediate layer - Multivariate community analyses · Ordination

- Resale or republication not permitted without written consent of the publisher

\section{INTRODUCTION}

Macrozooplankton plays a significant role in the pelagic ecosystem as food for fish, marine mammals, and marine birds, and as predators on copepods and/or fish larvae (Bamstedt 1988, 1998, Dalpadado et al. 1998, Mackas et al. 2001). Studies of the abundance and distribution of macrozooplankton are therefore important for understanding their role in the ecosys- tem (Dalpadado et al. 1998). In the lower St. Lawrence Estuary (LSLE) and the NW Gulf of St. Lawrence (NW GSL), few studies have examined the distribution, species composition, and abundance of macrozooplankton. Most previous studies have focused on the dense aggregations of euphausiids in the northern GSL (e.g. Berkes 1976, 1977, Sameoto 1976) and at the head of the Laurentian Channel (e.g. Simard et al. 1986a, Simard \& Lavoie 1999, Lavoie et al. 2000). On the other 
hand, apart from a few rudimentary taxonomic lists (see reviews in Runge \& Simard 1990, de Lafontaine et al. 1991, Brunel et al. 1998), the distribution and the interannual variations in the abundance of the main macrozooplankton groups (hyperiid amphipods, chaetognaths, mysids, ctenophores, and jellyfish) have never been examined in the LSLE and the GSL.

A number of integrated oceanographic and/or biological approaches have recently been used to examine the variable distribution and abundance of both krill and mesozooplankton in the LSLE (see Simard et al. 1986a,b, Runge \& Simard 1990, Plourde \& Runge 1993, Simard 1996, Runge et al. 1999, Simard \& Lavoie 1999, Zakardjian et al. 1999, Lavoie et al. 2000, Plourde et al. 2001, 2002, 2003). A conclusion common to all these studies is that the abundance and distribution of krill in the upper part of the LSLE and the horizontal distribution of the common pelagic copepods Calanus finmarchicus and C. hyperboreus in the LSLE are controlled by the 2-layer estuarine circulation, the strong vertical currents at the head of the Laurentian Channel (LC), and the stage-specific vertical distribution of the various species.

On the other hand, other studies have shown that the recent cold period observed since the mid 1980s in the GSL/LSLE region (see 'Physical oceanography of the study area') has influenced the distribution and abundance of various mesozooplankton and macrozooplankton species as well as some benthic species. Indeed, the last cold period in the GSL/LSLE region appears to be related to a dramatic increase in abundance of the midwater arctic copepod Metridia longa and the subsequent decline in the relative abundance of Calanus spp. (Plourde et al. 2002). Moreover, Harvey et al. (2002) observed that the abundance of the arctic hyperiid amphipod Themisto libellula increased from 0.17 ind. $\mathrm{m}^{-2}$ in 2000 to 10 ind. $\mathrm{m}^{-2}$ in 2001. This is the largest increase in abundance of this species in the last decade. Finally, the recent cold period was linked with an increase in the extent of the spatial distribution of snow crabs Chionoecetes opilio and a decline in their egg production (Sainte-Marie \& Gilbert 1998).

Thus, since the distribution and abundance of species of krill, hyperiid amphipods, and mesozooplankton in the GSL/LSLE region appear to be strongly related to the general circulation pattern and/or the interannual variations of the cold intermediate layer (CIL) thermal properties, we can hypothesize that the abundance and distribution of other macrozooplankton groups will also be affected by these environmental variables. The primary aim of this study was to describe the species composition and distribution of macrozooplankton in the LSLE and the NW GSL. Investigations were carried out in spring and fall 1998, 2000, and 2001. The interannual variations in the abundance of euphausiids, hyperiid amphipods, chaetognaths, mysids, and jellyfish are discussed in relation to the circulation pattern and the interannual variations in the thermal properties of the 3 major water masses in this region, particularly the CIL. The other goal was to assess the abundance, composition and role of macrozooplankton as food for higher trophic levels and its potential for regulating secondary production in the LSLE and the NW GSL.

\section{PHYSICAL OCEANOGRAPHY OF THE STUDY AREA}

The LSLE and NW GSL are 2 hydrographically complex areas under the influence of both estuarine and marine processes (Fig. 1). The LSLE is a long (200 km) and wide (20 to $40 \mathrm{~km}$ ) marine estuary characterized by the LC, a deep (>350 m) marine valley originating at the margin of the continental shelf and ending abruptly at the head of the LSLE, where the depth decreases from 300 to $50 \mathrm{~m}$ over less than $20 \mathrm{~km}$. The summer surface circulation is generally characterized by a seaward jetlike flow along the south shore that forms the Gaspé Current in the NW GSL and by the presence of several fronts and mesoscale features (Ingram \& El-Sabh 1990, Marsden \& Gratton 1998). The Gaspé Current freshwater outflow is compensated by slow upward advection of deep water through the LC (El-Sabh 1979, Ingram 1979, Tee \& Lim 1987, Ingram \& El-Sabh 1990, Koutitonsky \& Bugden 1991). On the other hand, the NW GSL is characterized by the presence of a quasi-permanent cyclonic eddy to the west of Anticosti Island (Anticosti Gyre, AG) (Trites 1972, El-Sabh 1976, Sévigny et al. 1979, Tang 1980), whose vertical density structure forms an upward dome with the highest density in the middle (Koutitonsky \& Bugden 1991).

The summertime water column in the LSLE and the NW GSL is a 3-layer system (Bjerkan 1919, Lauzier \& Trites 1958). The surface mixed layer varies between 10 and $20 \mathrm{~m}$ in thickness, has relatively low salinity (25 to 32 ) and temperatures ranging from 3 to $14^{\circ} \mathrm{C}$ (e.g. de Lafontaine et al. 1991, Koutitonsky \& Bugden 1991). The summertime CIL is the remnant of the nearfreezing winter surface waters that are progressively warmed thereafter, initially formed partly by winter cooling within the Gulf and partly by the advection of Labrador Shelf water via the strait of Belle Isle and Cabot strait (Lauzier \& Bailey 1957, Forrester 1964, Banks 1966). We will adopt the commonly used definition of the CIL; that is, water temperature lower than or equal to $3^{\circ} \mathrm{C}$ (Gilbert \& Pettigrew 1997). The temperature minimum occurs around 60 to $75 \mathrm{~m}$ and the layer extends as deep as 150 to 170 m (Gilbert \& Pettigrew 


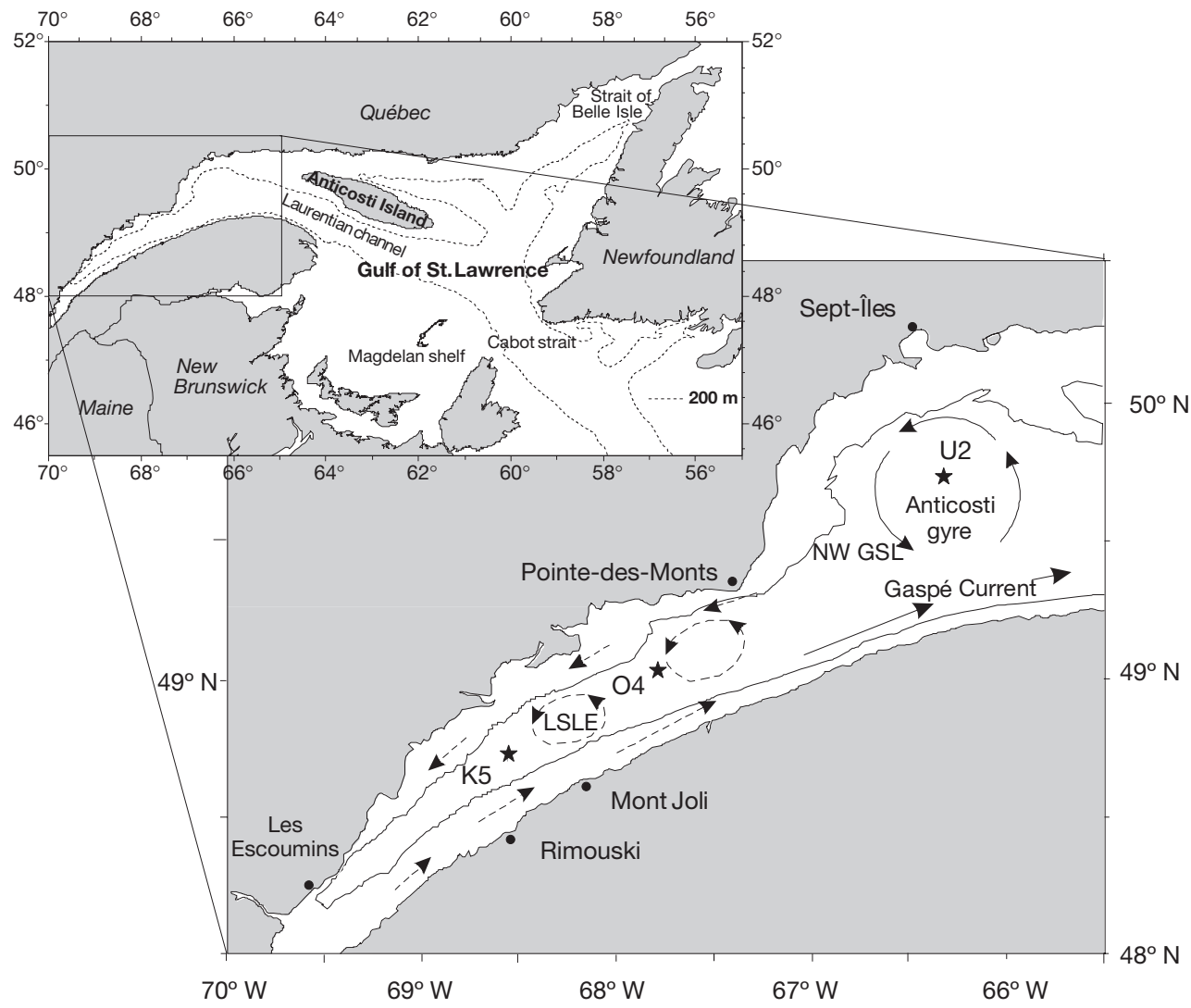

Fig. 1. Map of the LSLE (Lower St. Lawrence Estuary) and the NW GSL (NW Gulf of St. Lawrence) showing the sampling stations $(\star)$, the Laurentian Channel identified by the $200 \mathrm{~m}$ isobath (solid line), and the general surface circulation pattern in early summer (arrows) (adapted from Plourde et al. 2001)

1997). Finally, the deep layer (typically $>150 \mathrm{~m}$ ), which originates from the inflow of a mixture of Labrador and Atlantic Slope waters to the LC, is warmer $\left(3\right.$ to $\left.5^{\circ} \mathrm{C}\right)$ and saltier $(\sim 34)$ than the CIL, and both the temperature and the salinity vary little over seasons and years (Lauzier \& Trites 1958, Ingram 1979).

For many decades, the LSLE and NW GSL have been subject to important climatic variations. Indeed, the sea-ice cover, temperature, salinity, and circulation exhibit interannual variability attributed to interactions with the atmosphere (heat exchange between water and air, precipitation, evaporation, ice formation) and water mass exchanges between the GSL and the Atlantic ocean through Cabot and Belle Isle straits (Bugden 1991, Gilbert \& Pettigrew 1997, Drinkwater et al. 1999, 2000, Saucier et al. 2003). In particular, the CIL core temperature and thickness are subject to significant interannual changes in both the LSLE and NW GSL (Gilbert \& Pettigrew 1997). From 1948 to 2001, there were 3 generally warm periods (1949-1955, 1965-1971, 1980-1983) and 3 generally cold periods (1961-1964, 1972-1977, 1986-1998). The most recent cold period (1986-1998) was the longest (13 yr) and the most intense of all with a mean CIL core temperature index of $-0.74^{\circ} \mathrm{C}$ and holding the 11 coldest years in the entire $53 \mathrm{yr}$ record up to that time. At the end of this recent cold period, the CIL core temperature increased from $-0.77^{\circ} \mathrm{C}$ to $0.10^{\circ} \mathrm{C}$ from 1998 to 2000 , and then decreased again to $-0.10^{\circ} \mathrm{C}$ in 2001 (D. Gilbert pers. comm.). Thus, based on the CIL core temperature index, the $4 \mathrm{yr}$ period from 1998 to 2001 showed a particularly large interannual change.

\section{MATERIALS AND METHODS}

Field sampling. Six cruises were carried out in the LSLE and the NW GSL in spring and fall 1998, 2000, and 2001. One station per sampling zone (LSLE and NW GSL) was sampled during each cruise. For the LSLE region, Stn K5 $\left(48^{\circ} 40^{\prime} \mathrm{N}, 68^{\circ} 35^{\prime} \mathrm{W}\right)$ was sampled in spring and fall 1998 whereas Stn O4 $\left(49^{\circ} 01^{\prime} \mathrm{N}\right.$, $67^{\circ} 44^{\prime} \mathrm{W}$ ) was sampled in spring and fall 2000 and 2001, because of ship-time constraints (Fig. 1). For the NW GSL region, Stn U2 $\left(49^{\circ} 43^{\prime} \mathrm{N}, 66^{\circ} 15^{\prime} \mathrm{W}\right)$ was sampled during each cruise (Fig. 1). A vertical profile of 
temperature and salinity was obtained at each station using a Sea-Bird SBE 911plus CTD. Immediately following the CTD cast, zooplankton samples were collected using a $1 \mathrm{~m}^{2}$ BIONESS sampler (Sameoto et al. 1980) equipped with 9 opening/closing nets having a $250 \mu \mathrm{m}$ mesh size (except in fall 1998 and 2001 when the mesh size used was $333 \mu \mathrm{m}$ ). The BIONESS sampler was first sent to $5 \mathrm{~m}$ above the bottom with the nets closed and then towed obliquely toward the surface with the ship traveling at ca. 2 to 3 knots. Seven depth strata were sampled: $0-25,25-50,50-100,100-150$, 150-200, 200-250, and $250 \mathrm{~m}$-bottom. At each station, the BIONESS sampler was used a minimum of 3 times, with at least one at mid-day and mid-night respectively, in order to evaluate the mean total abundance of macrozooplankton.

A total of 66 BIONESS tows (with 7 strata each tow) were collected. The total filtered volume in each stratum was estimated using a General Oceanic flow meter (model 2031H) installed in the mouth of each net of the BIONESS. At the end of each tow, nets were rinsed from the exterior and the contents of the codends were preserved in $4 \%$ buffered formaldehyde for later analysis. In the laboratory, the macrozooplankton were sorted, identified to the species level, and counted in all samples. The macrozooplankton include all zooplankton organisms $\geq 3 \mathrm{~mm}$ other than copepods.

Data analysis. To follow the temporal evolution of the physical properties, we used all available CTD profiles obtained in each sampling zone for each sampling period. Eleven variables describing the environmental conditions at each station were calculated from each profile: the upper $\left(z_{\mathrm{i}}\right)$ and lower $\left(z_{\mathrm{f}}\right)$ limits of the CIL at $3^{\circ} \mathrm{C}$, the CIL core temperature $\left(T_{\min }\right)$, the depth of the CIL core temperature $\left(z_{T_{\min }}\right)$, the CIL thickness at $3^{\circ} \mathrm{C}$ $\left(\Delta z_{3^{\circ} \mathrm{C}}\right)$ and $1{ }^{\circ} \mathrm{C}\left(\Delta z_{1{ }^{\circ} \mathrm{C}}\right)$ (Fig. 2) (Gilbert \& Pettigrew $1997)$, the average salinity of the CIL $\left(S_{\mathrm{CIL}}\right)$, the average temperature $\left(T_{\mathrm{S}}\right)$ and salinity $\left(S_{\mathrm{S}}\right)$ of the surface layer, defined as the part of the water column above the $3{ }^{\circ} \mathrm{C} \mathrm{CIL}$, and the average temperature $\left(T_{\mathrm{d}}\right)$ and salinity $\left(S_{\mathrm{d}}\right)$ of the deep layer, defined as waters below the CIL. Each physical variable was normalized into a dimensionless parameter for inter-comparison by subtracting its mean value and dividing the result by the standard deviation. Finally, the average temperature and salinity profiles were calculated in each region for each sampling period.

The number of macrozooplankton individuals collected in the different depth strata was integrated over the entire water column to obtain the number of individuals per $\mathrm{m}^{2}$. The relative abundance (\%) of each macrozooplankton group for each sampling date in the 2 sampling zones was also calculated.

Multivariate analyses were carried out using the PRIMER software (Plymouth Routines in Multivariate
Ecological Research) (Clarke \& Gorley 2001) to objectively identify the spatio-temporal changes in the structure of the macrozooplankton community (composition and abundance) and to determine the relative contribution of the 11 normalized physical parameters (described above) to the changing structure observed in both sampling zones. A Euclidean distance matrix derived from the mean of normalized dimensionless physical parameters was first calculated (Clarke \& Warwick 2001). Secondly, replicate variability of physical parameters was examined by similarity analysis and non-metrical multi-dimensional scaling (NMDS). Thirdly, 1-way analyses of similarities (ANOSIM) (Clarke \& Green 1988) were used to test for differences among stations, seasons, and years in each region. ANOSIM generates an $\mathrm{R}$ value that is between -1 and +1 , with a value of 0 indicating no differences among stations/seasons/years (Clarke \& Ainsworth 1993).

Generally, $\mathrm{R}$ lies between 0 and +1 , its magnitude depending on the amount by which stations, seasons, and years differ (Chapman \& Underwood 1999). Its value is at least as important as its statistical significance (p) (Clarke \& Gorley 2001). Indeed, there are big differences, with the groups being either well separated $(R>0.75)$, overlapping but clearly different $(R>$ $0.50)$, overlapping but different $(\mathrm{R}>0.25)$, or barely

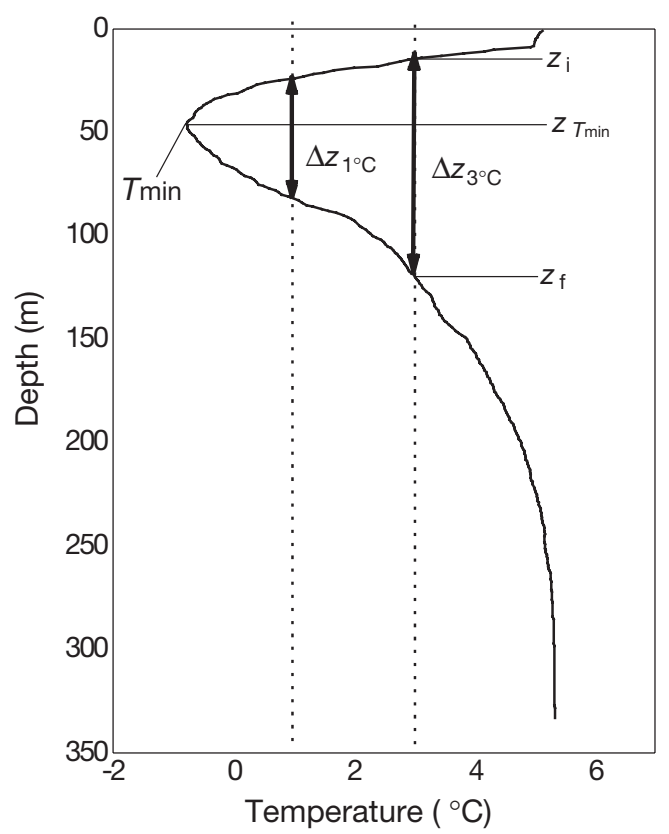

Fig. 2. Typical profile of temperature taken in the NW GSL in spring 1999. The cold intermediate layer (CIL) can be defined by the following parameters: CIL thickness at $3^{\circ} \mathrm{C}\left(\Delta z_{3^{\circ} \mathrm{C}}\right)$ and $1^{\circ} \mathrm{C}\left(\Delta z_{1^{\circ} \mathrm{C}}\right)$ (see arrows); depth at which the CIL begins and ends $\left(z_{\mathrm{i}}\right.$ and $\left.z_{\mathrm{f}}\right)$ at $3^{\circ} \mathrm{C}_{\mathrm{i}}$ and depth $\left(z_{T_{\min }}\right)$ and temperature $\left(T_{\min }\right)$ at the core of that layer (adapted from Gilbert \& Pettigrew 1997) 
separable $(\mathrm{R}<0.25)$ (Clarke \& Gorley 2001). These differences were then tested for each physical parameter by analysis of variance (ANOVA), and physical parameters for which the abundance was significantly different between groups were defined as indicators of that group. The ANOVA was followed by a posteriori comparisons using a Tukey test.

The second step of the analysis was to identify the regional and interannual variability in macrozooplankton assemblages using the same statistical procedure described above (NMDS, ANOSIM, and ANOVA), except that macrozooplankton abundances were $\log (x+1)$ transformed to avoid the strong influence of the most abundant taxa and the NMDS was applied to a Bray-Curtis similarity matrix (Bray \& Curtis 1957). A discriminant analysis was performed as the final step to determine the influence of the physical parameter properties responsible for the separation of groups. This analysis was carried out using the forward stepping method in SYSTAT 10, which permits the identification of the useful subset of predictor variables when strong correlations exist among the candidate predictor variables (Engelman 2000).

\section{RESULTS}

\section{Variations in the environmental conditions}

The mean vertical profiles of temperature and salinity in the LSLE and in the NW GSL show the presence of a 3-layer system, with a well-developed CIL in both regions in spring and fall of the 3 sampled years $(1998,2000$, and 2001) (Fig. 3). The interannual and interseasonal variations in environmental conditions were more pronounced in the LSLE than the NW GSL, especially for the CIL properties such as the CIL thickness at $3^{\circ} \mathrm{C}\left(\Delta z_{3^{\circ}} \mathrm{C}\right)$, the CIL core temperature $\left(T_{\min }\right)$, and the depth of the CIL core temperature $\left(z_{T_{\min }}\right)$. Indeed, the $\Delta z_{3^{\circ} \mathrm{C}}$ varied between 77 and $137 \mathrm{~m}$ in the LSLE and between 101 and $127 \mathrm{~m}$ in the NW GSL. Likewise, $T_{\min }$ and $z_{T_{\min }}$ varied between -1.1 and $0.5^{\circ} \mathrm{C}$, and 47 and $93 \mathrm{~m}$ in the LSLE and between -1.0 and $0.6^{\circ} \mathrm{C}$, and 20 and $48 \mathrm{~m}$ in the NW GSL. Some of the interannual variability of fall conditions in the
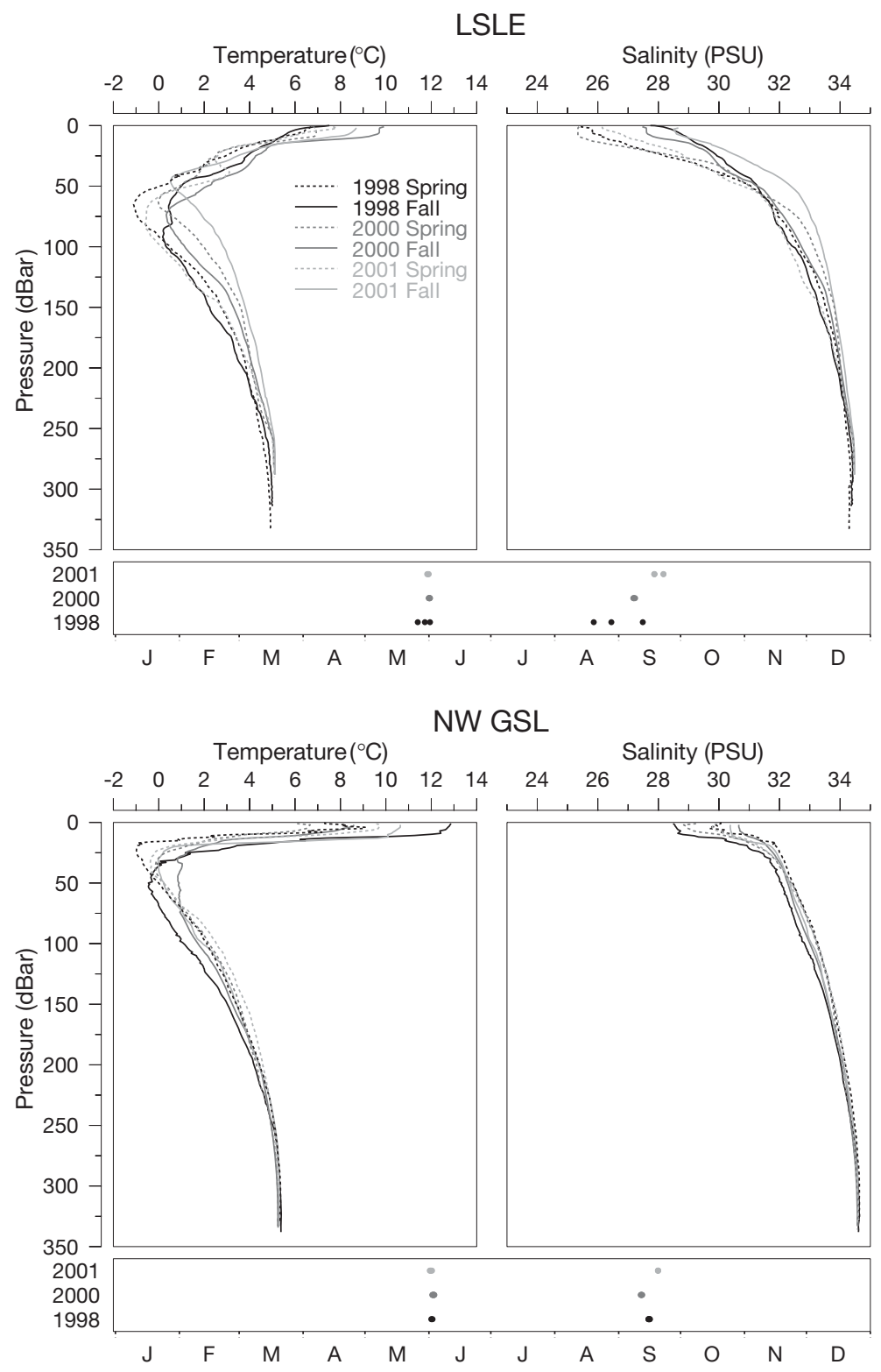

Fig. 3. Average vertical profiles of temperature and salinity taken in the LSLE and in the NW GSL during spring and fall 1998, 2000, and 2001. Lower landscape panels indicate on what day of the year the various profiles were sampled for each year and region

LSLE could be attributed to the later data collection dates in 2001 because the CIL is eroded (thinned and warmed) as the season progresses (Banks 1966, Ingram 1979, Gilbert \& Pettigrew 1997) but this is not a major effect. For example, the thinning rate of the CIL in the estuary is about $9.6 \mathrm{~m} \mathrm{mo}^{-1}$ (Gilbert \& Pettigrew 1997) and would contribute on the order of $5 \mathrm{~m}$ to the mean thickness in 2001 if this correction were made. This is less than the standard error and also less than the interannual variability (see later Table 5 describing mean annual conditions). 
The NW GSL exhibited more variability than the LSLE concerning surface temperature: between 6 and $10^{\circ} \mathrm{C}$ in the LSLE, and between 6 and $13^{\circ} \mathrm{C}$ in the NW GSL. The salinity was generally lower in the LSLE (23.90 to 28.20) than in the NW GSL (27.10 to 30) for all sampling dates. In contrast to the variability of surface conditions, the deep layer temperature and salinity profiles did not vary much, either seasonally or annually, in both regions (Fig. 3).

\section{Macrozooplankton species composition and abundance}

A total of 15 macrozooplankton species were identified in both regions (LSLE and NW GSL) in spring and fall of the 3 sampled years (1998, 2000, and 2001) (Table 1). Five species (Themisto gaudichaudii, Scina borealis, Hyperoche sp., Thysanoessa inermis, and Thysanoessa longicaudata) were found in less than $50 \%$ of the BIONESS tows whereas 2 taxa (Boreomysis arctica and Sagitta elegans) were found in all BIONESS tows (Table 1). The mean abundance of the various taxa varied between 0.03 and 124.93 ind. $\mathrm{m}^{-2}$ and only 5 species (Thysanoessa raschii, B. arctica, $S$. elegans, Aglantha digitale, and Dimophyes arctica) had a mean abundance greater than 10 ind. $\mathrm{m}^{-2}$ (Table 1).

Table 1. Summary of macrozooplankton identification and abundance in the LSLE and the NW GSL. Percentage of occurrence $(\% \mathrm{O})$, range and mean abundance (ind. $\mathrm{m}^{-2}$ ) with standard error (SE) are presented

\begin{tabular}{|c|c|c|c|}
\hline Taxon & $\% \mathrm{O}$ & $\begin{array}{c}\text { Range } \\
\text { (ind. } \mathrm{m}^{-2} \text { ) }\end{array}$ & $\begin{array}{l}\text { Mean (SE) } \\
\left(\text { ind. } \mathrm{m}^{-2} \text { ) }\right.\end{array}$ \\
\hline \multicolumn{4}{|l|}{ Hyperiid amphipods } \\
\hline Themisto abyssorum & 97 & $0-79$ & $9.33(3.68)$ \\
\hline Themisto gaudichaudii & 48 & $0-2$ & $0.27(0.09)$ \\
\hline Themisto libellula & 62 & $0-58$ & $2.56(2.03)$ \\
\hline Scina borealis & 39 & $0-3$ & $0.37(0.16)$ \\
\hline Hyperoche sp. & 18 & $0-1$ & $0.12(0.07)$ \\
\hline \multicolumn{4}{|l|}{ Euphausiids } \\
\hline Meganyctiphanes norvegica & a 95 & $0-89$ & $9.60(4.34)$ \\
\hline Thysanoessa inermis & 44 & $0-3$ & $0.36(0.16)$ \\
\hline Thysanoessa longicaudata & 14 & $0-0.5$ & $0.03(0.01)$ \\
\hline $\begin{array}{l}\text { Thysanoessa raschii } \\
\text { Mysid }\end{array}$ & 82 & $0-138$ & $16.87(3.74)$ \\
\hline $\begin{array}{l}\text { Boreomysis arctica } \\
\text { Chaetognath }\end{array}$ & 100 & $42-231$ & $124.93(11.81)$ \\
\hline $\begin{array}{l}\text { Sagitta elegans } \\
\text { Hydromedusa }\end{array}$ & 100 & $2-139$ & $25.44(5.97)$ \\
\hline Aglantha digitale & 94 & $0.2-50$ & $12.46(2.78)$ \\
\hline $\begin{array}{l}\text { Ctenophore spp. } \\
\text { Siphonophore }\end{array}$ & 71 & $0-10$ & $1.02(0.39)$ \\
\hline $\begin{array}{l}\text { Dimophyes arctica } \\
\text { Polychaete }\end{array}$ & 91 & $0-32$ & $11.46(2.11)$ \\
\hline Tomopteris sp. & 76 & $0-3$ & $0.75(0.18)$ \\
\hline
\end{tabular}

Mysids were clearly dominant during spring and fall of each year in both sampling regions, accounting for an average of $58 \%$ (LSLE) and $59 \%$ (NW GSL) of the macrozooplankton community (Fig. 4). Euphausiids were the second most important group in the LSLE (average $23 \%$ ) and chaetognaths in the NW GSL (average 16\%). The least important groups for each region were hyperiid amphipods in the LSLE and euphausiids in the NW GSL. Each typically represented less than $5 \%$ of the total macrozooplankton abundance in the corresponding region (Fig. 4). Little difference was observed between spring and fall in all years for both regions, except in 1998 for euphausiids in the LSLE and for hyperiid amphipods in the NW GSL (Fig. 4). On the other hand, the relative abundance of the macrozooplankton groups varied as a function of the year in both regions (see Fig. 4).

\section{Regional variations of environmental conditions}

The NMDS ordination comparing the 11 physical variables between stations for the 6 sampling dates

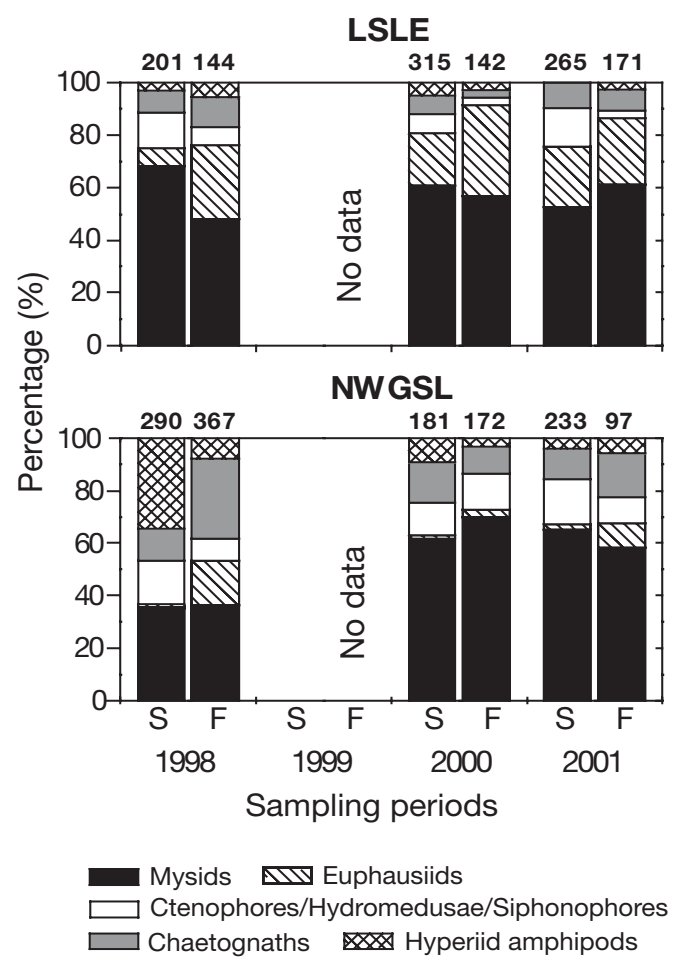

Fig. 4. Relative abundance of the major groups of macrozooplankton found in the LSLE and in the NW GSL in spring (S) and fall (F) 1998, 2000, and 2001. Ctenophores, Hydromedusae, and Siphonophores were combined because of the low relative abundance observed for each group. Numbers above bars indicate the mean total abundance (ind. $\mathrm{m}^{-2}$ ) of macrozooplankton for each region, season, and year 

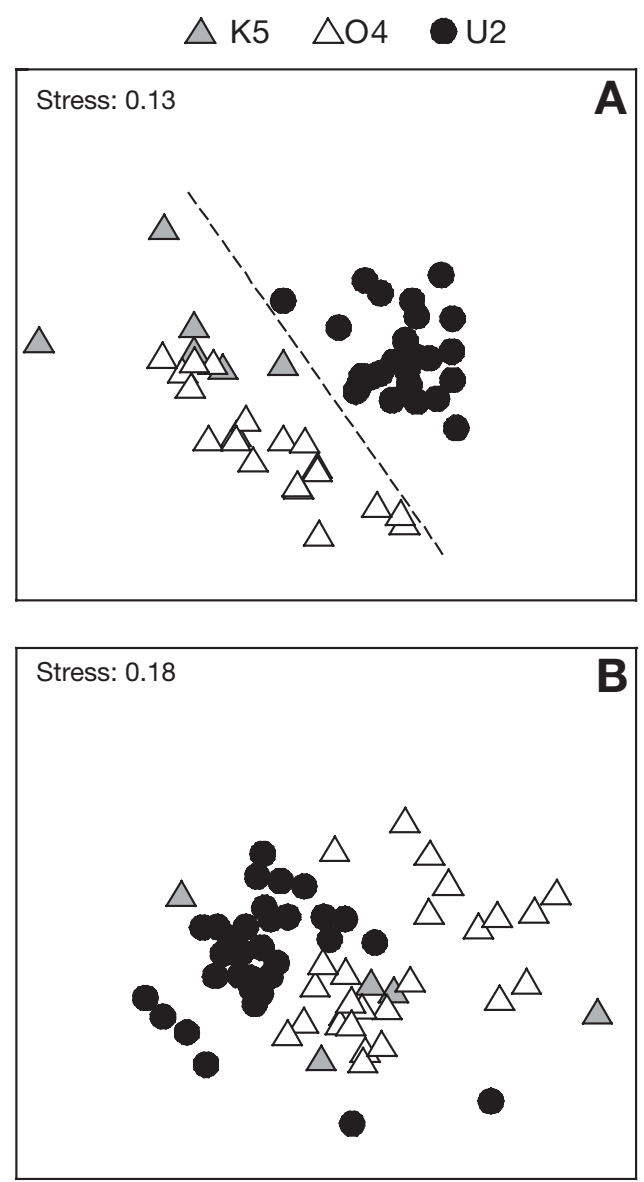

Fig. 5. Regional analysis showing discrimination between the LSLE (Stns K5 and O4) and the NW GSL (Stn U2). (A) NMDS ordination based on the normalized Euclidean distance matrix derived from the mean of dimensionless physical parameters. Dashed line emphasises the distinctiveness of the 2 sampling regions. (B) NMDS ordination based on Bray-Curtis indices of similarity derived from log-transformed mean abundance of macrozooplankton species

(Fig. 5A) showed that Stn U2 is clearly different from Stns K5 and O4 while the separation between Stn K5 and $\mathrm{O} 4$ is less clear (Fig. 5A). Moreover, U2 samples form denser clusters than those of $\mathrm{K} 5$ and O4, indicating that the interannual variations of environmental variables were more pronounced at K5 and O4 in the estuary than at U2 in the Gulf (Fig. 5A). These results were confirmed by the ANOSIM test, which showed that there was no significant environmental difference between K5 and O4 in the LSLE $(\mathrm{R}=0.273, \mathrm{p}=0.01)$ but significant differences between K5 and U2 (R = 0.901, $\mathrm{p}=0.001)$, and between $\mathrm{O} 4$ and U2 $(\mathrm{R}=0.791$, $\mathrm{p}=0.001)$.

The ANOVA results showed that both surface and deep layers (defined as above and below the deep $3^{\circ} \mathrm{C}$ isotherms of the CIL) were fresher and colder in the
LSLE (K5 and O4) than in the NW GSL (U2) (Table 2). Moreover, the CIL started deeper in the LSLE than in the NW GSL and the CIL core temperature was located twice as deep in the LSLE compared to the NW GSL. The CIL was also less saline in the LSLE than the NW GSL (Table 2).

\section{Regional variations in the macrozooplankton community structure}

A NMDS analysis was also carried out to examine the biological differences between the sampled stations for all years and seasons (Fig 5B). This analysis confirmed the difference between the LSLE and NW GSL regions, with 2 groups of stations clearly standing out: (1) O4 and K5 in the LSLE, and (2) U2 in the NW GSL (Fig. 5B). This result was confirmed by the ANOSIM test, which showed that there was no significant biological difference between K5 and O4 $(\mathrm{R}=$ $0.225, \mathrm{p}=0.051$ ) but there was a significant difference between K5 and U2 $(R=0.598, p=0.002)$, and between $\mathrm{O} 4$ and $\mathrm{U} 2(\mathrm{R}=0.479, \mathrm{p}=0.001)$.

According to the ANOVA results comparing the mean abundance of the dominant species in each sampling zone (Table 3), the difference between the LSLE and the NW GSL lies in the greater abundance of 2 species of euphausiids, Meganyctiphanes norvegica and Thysanoessa raschii in the LSLE; and a greater abundance of 3 hyperiid amphipods, Themisto abyssorum, Themisto gaudichaudii, and Scina borealis; 1 chaetognath, Sagitta elegans; 1 siphonophore, Dimophyes arctica; and 1 polychaete, Tomopteris sp. in the NW GSL (Table 3). The abundance of the most abundant macrozooplankton species Boreomysis arctica did not vary significantly between regions (Table 3).

The physical parameters that could account for the regional variability between the above 2 assemblages of macrozooplankton were identified using discriminant analysis. The first 2 functions of this discriminant analysis explained $100 \%$ of the inter-group variance (Wilks' $\lambda=0.094, \mathrm{p}<0.001$ ) and resulted in the proper a posteriori classification of all of the physical parameters. The 2 groups are discriminated along the first axis.

Five environmental variables were identified by discriminant analysis as separating out the variance between groups, 3 of which are associated with the CIL: the CIL thickness at $1^{\circ} \mathrm{C}\left(\Delta z_{1}{ }^{\circ} \mathrm{C}\right)$, the CIL core temperature $\left(T_{\min }\right)$, the depth of the CIL core temperature $\left(z_{T_{\min }}\right)$, and the average temperature $\left(T_{\mathrm{d}}\right)$ and salinity $\left(S_{\mathrm{d}}\right)$ of the deep layer (Table 4$)$. An examination of the environmental characteristics of each group (Table 2) reveals that the assemblage of macrozooplankton taxa 
Table 2. Mean (SE) of physical parameters and results of 1-way ANOVAs. Physical parameters with averages that differed significantly between sampling regions are in bold

\begin{tabular}{|c|c|c|c|c|}
\hline Physical parameters & $\begin{array}{c}\text { LSLE } \\
(\mathrm{n}=26)\end{array}$ & $\begin{array}{l}\text { NW GSL } \\
(\mathrm{n}=27)\end{array}$ & $F$ & $\mathrm{p}$ \\
\hline \multicolumn{5}{|l|}{ Surface layer } \\
\hline Mean temperature $\left(T_{\mathrm{s}}\right)\left({ }^{\circ} \mathrm{C}\right)$ & $5.52(0.12)$ & $7.46(0.32)$ & 30.64 & $<0.001$ \\
\hline Mean salinity $\left(S_{\mathrm{s}}\right)$ & $27.76(0.31)$ & $29.98(0.12)$ & 41.08 & $<0.001$ \\
\hline \multicolumn{5}{|l|}{ CIL } \\
\hline Upper limit at $3^{\circ} \mathrm{C}\left(z_{\mathrm{i}}\right)(\mathrm{m})$ & $28.39(2.10)$ & $14.70(0.77)$ & 35.05 & $<0.001$ \\
\hline Lower limit at $3^{\circ} \mathrm{C}\left(z_{\mathrm{f}}\right)(\mathrm{m})$ & $139.79(4.24)$ & $131.11(2.51)$ & 2.91 & 0.090 \\
\hline Thickness at $3^{\circ} \mathrm{C}\left(\Delta z_{3^{\circ} \mathrm{C}}\right)(\mathrm{m})$ & $111.40(4.31)$ & $116.41(2.16)$ & 1.01 & 0.320 \\
\hline Thickness at $1^{\circ} \mathrm{C}\left(\Delta z_{1}{ }^{\circ} \mathrm{C}\right)(\mathrm{m})$ & $45.94(3.73)$ & $52.01(2.18)$ & 1.85 & 0.180 \\
\hline Core temperature $\left(T_{\min }\right)\left({ }^{\circ} \mathrm{C}\right)$ & $-0.19(0.10)$ & $-0.22(0.10)$ & 0.04 & 0.840 \\
\hline Depth of the $T_{\min }\left(z_{T_{\min }}\right)(\mathrm{m})$ & $68.02(2.51)$ & $35.00(1.72)$ & 110.81 & $<0.001$ \\
\hline Mean salinity $\left(S_{\mathrm{CIL}}\right)$ & $32.18(0.07)$ & $32.61(0.02)$ & 37.79 & $<0.001$ \\
\hline \multicolumn{5}{|l|}{ Deep layer } \\
\hline Mean temperature $\left(T_{d}\right)\left({ }^{\circ} \mathrm{C}\right)$ & $4.22(0.03)$ & $4.56(0.02)$ & 89.53 & $<0.001$ \\
\hline Mean salinity $\left(S_{d}\right)$ & $34.07(0.01)$ & $34.21(0.01)$ & 63.85 & $<0.001$ \\
\hline
\end{tabular}

in the NW GSL, the seasonal $(\mathrm{R}=$ 0.831, $\mathrm{p}=0.001)$ and interannual $(\mathrm{R}=$ $0.804, \mathrm{p}=0.001$ ) variability were similar. Furthermore, in the LSLE the interannual variations were more pronounced between 1998 and 2000 than between 1998 and 2001 (Fig. 6A). In the NW GSL, there was also a clear difference between spring and fall in all years. Moreover, the environmental variables of 1998 are clearly separated from those of 2000 and 2001 (Fig. 6B). Spring samples from 1998, 2000, and 2001 formed denser clusters than those of fall, indicating that the interannual variations of environmental variables were more pronounced in fall than in spring in both regions, although this trend is less clear in the NW GSL than in the LSLE (Fig. 6A,B).

from the LSLE was associated with a CIL that was thinner, warmer, and had a $T_{\min }$ encountered deeper than the assemblage from the NW GSL (Table 2). Moreover, the deep layer was colder and fresher in the LSLE than in the NW GSL (Table 2).

\section{Interannual variations of environmental conditions}

Fig. 6A and B show results of the NMDS analyses carried out to examine the environmental differences between years in the LSLE and NW GSL. These analyses revealed significant interannual variations in both the LSLE $(\mathrm{R}=0.77, \mathrm{p}<0.01)$ and the NW GSL $(\mathrm{R}=0.80, \mathrm{p}<0.01)$. Indeed, the ANOSIM test confirmed significant differences between all pairs of years in the LSLE (1998-2000: $\mathrm{R}=0.801, \mathrm{p}=$ $0.001 ;$ 1998-2001: $\mathrm{R}=0.750, \mathrm{p}=0.002$; 2000-2001: $\mathrm{R}=0.873, \mathrm{p}=0.001$ ) and the NW GSL (1998-2000: R = 0.918, $\mathrm{p}=0.001 ; 1998-2001: \mathrm{R}=0.695, \mathrm{p}=$ 0.003; 2000-2001: $\mathrm{R}=0.836, \mathrm{p}=0.001$ ).

The NMDS ordination comparing the seasonal and the interannual variations of the environmental variables in both regions (Fig. 6A,B) showed that for the LSLE, the seasonal variation $(\mathrm{R}=0.888, \mathrm{p}=0.001)$ was more important than the interannual variability $(\mathrm{R}=0.771, \mathrm{p}=0.001)$ whereas
Table 3. Mean (SE) numerical abundances (ind. $\mathrm{m}^{-2}$ ) of dominant species and results of 1-way ANOVA. Abundance was transformed using $\log (x+1)$. Species with mean abundance that differed significantly between sampling regions are in bold

\begin{tabular}{|lcrrr|}
\hline Species & LSLE & NW GSL & $F$ & p \\
\hline Hyperiid amphipods & & & & \\
$\quad$ Themisto abyssorum & $3.62(1.31)$ & $14.76(3.11)$ & 32.87 & $<\mathbf{0 . 0 0 1}$ \\
$\quad$ Themisto gaudichaudii & $0.14(0.04)$ & $0.37(0.07)$ & 7.29 & $\mathbf{0 . 0 0 9}$ \\
$\quad$ Themisto libellula & $0.97(0.46)$ & $4.07(1.90)$ & 2.39 & 0.127 \\
$\quad$ Scina borealis & $0.13(0.05)$ & $0.55(0.13)$ & 9.56 & $\mathbf{0 . 0 0 3}$ \\
$\quad$ Hyperoche sp. & $0.06(0.04)$ & $0.16(0.05)$ & 2.34 & 0.131 \\
Euphausiids & & & & \\
$\quad$ Meganyctiphanes norvegica & $16.92(4.24)$ & $2.78(0.44)$ & 22.66 & $<\mathbf{0 . 0 0 1}$ \\
$\quad$ Thysanoessa inermis & $0.34(0.10)$ & $0.40(0.13)$ & 0.01 & 0.951 \\
$\quad$ Thysanoessa longicaudata & $0.03(0.02)$ & $0.04(0.02)$ & 0.16 & 0.692 \\
$\quad$ Thysanoessa raschii & $33.59(6.75)$ & $2.02(1.03)$ & 73.13 & $<\mathbf{0 . 0 0 1}$ \\
Mysid & & & & \\
$\quad$ Boreomysis arctica & $123.93(9.83)$ & $128.01(6.93)$ & 0.56 & 0.456 \\
Chaetognath & & & & \\
$\quad$ Sagitta elegans & $16.02(1.97)$ & $34.23(5.10)$ & 23.67 & $<\mathbf{0 . 0 0 1}$ \\
Hydromedusa & & & & \\
$\quad$ Aglantha digitale & $11.52(1.89)$ & $12.21(1.98)$ & 0.45 & 0.503 \\
Ctenophore spp. & $1.16(0.22)$ & $0.84(0.31)$ & 2.80 & 0.099 \\
Siphonophore & & & & \\
$\quad$ Dimophyes arctica & $7.25(1.12)$ & $14.30(1.53)$ & 10.60 & $\mathbf{0 . 0 0 2}$ \\
Polychaete & & & & \\
$\quad$ Tomopteris sp. & $0.51(0.11)$ & $0.90(0.12)$ & 6.42 & $\mathbf{0 . 0 1 4}$ \\
\hline
\end{tabular}


ture was colder in 1998 than in 2000 and 2001. Moreover, in the LSLE, the mean surface temperature was colder in 1998 than in 2000 and 2001. In contrast, the differences between years was less pronounced in the NW GSL than in the LSLE for the CIL but not for the surface layer, where the NW GSL differed more between years than the LSLE (see Fig. $7, T_{\mathrm{S}}$ ).

\section{Interannual variations of macrozooplankton community structure}

Since the community structure of macrozooplankton differed between the 2 sampled regions (LSLE and NW GSL), the interannual variation of the macrozooplankton community structure was studied separately in each zone.

According to the NMDS ordination (Fig. 6C,D) and the results of the ANOSIM test, significant interannual variations of the mean abundance of macrozooplankton species were observed in both the LSLE $(\mathrm{R}=0.724$, $\mathrm{p}=0.001)$ and the NW GSL $(\mathrm{R}=0.868, \mathrm{p}=0.001)$, respectively. Furthermore, seasonal variation in the LSLE $(\mathrm{R}=0.815, \mathrm{p}=0.001)$ was more important than the interannual variability $(\mathrm{R}=0.724, \mathrm{p}=0.001)$ whereas in the NW GSL, the seasonal $(R=0.830, p=$ $0.001)$ and interannual $(\mathrm{R}=0.868, \mathrm{p}=0.001)$ variability of macrozooplankton species abundance were similar. There was a clear difference between spring and fall in 1998, 2000, and 2001 in the LSLE (Fig. 6C), and in 1998 and 2000 in the NW GSL (Fig. 6D). The interannual variations were also more pronounced in fall than in spring in both regions.

According to the ANOVA results presented in Figs. 8 \& 9, 5 (Themisto abyssorum, Meganyctiphanes norvegica, Thysanoessa raschii, Sagitta elegans, and Aglantha digitale) and 7 (T. abyssorum, Themisto libellula, M. norvegica, T. raschii, S. elegans, A. digitale, and Dimophyes arctica) main indicator species varied significantly between years in the LSLE and in the NW GSL, respectively. On the other hand, the abundance of the most abundant macrozooplankton species, the mysid Boreomysis arctica, did not vary significantly between years or seasons in either the LSLE or the NW GSL.

Discriminant analyses were further used to identify the environmental factors responsible for the separation of the groups of years in both regions (Fig. 10). The

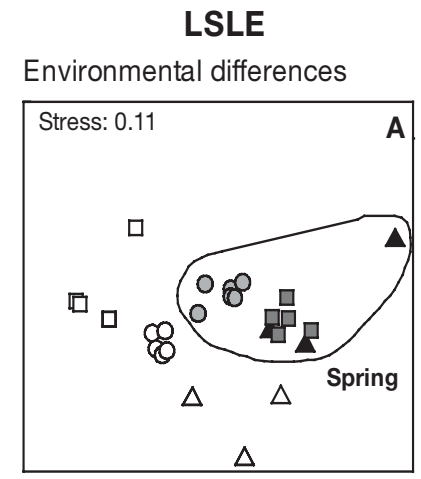

\begin{tabular}{|c|c|c|c|c|c|}
\hline \multirow[t]{3}{*}{ Physical parameter } & \multirow{3}{*}{$\begin{array}{l}\text { Regional } \\
\text { I } \\
100 \%\end{array}$} & \multicolumn{4}{|c|}{ Interannual } \\
\hline & & \multicolumn{2}{|c|}{ LSLE } & \multicolumn{2}{|c|}{ NW GSL } \\
\hline & & $\begin{array}{c}\mathrm{I} \\
74 \%\end{array}$ & $\begin{array}{c}\text { II } \\
26 \%\end{array}$ & $\begin{array}{c}\mathrm{I} \\
52 \%\end{array}$ & $\begin{array}{c}\text { II } \\
48 \%\end{array}$ \\
\hline \multicolumn{6}{|l|}{ Surface layer } \\
\hline Mean temperature $\left(T_{\mathrm{s}}\right)$ & & $-0.34(6)$ & -0.89 & $0.63(5)$ & $-1.35(4)$ \\
\hline Mean salinity $\left(S_{\mathrm{s}}\right)$ & & $0.46(5)$ & $-2.59(1)$ & $-1.00(3)$ & $-1.98(1)$ \\
\hline \multicolumn{6}{|l|}{ CIL } \\
\hline Upper limit at $3^{\circ} \mathrm{C}\left(z_{\mathrm{i}}\right)$ & & $1.39(3)$ & $1.77(2)$ & & \\
\hline Lower limit at $3^{\circ} \mathrm{C}\left(z_{\mathrm{f}}\right)$ & & & & $0.99(4)$ & $1.15(6)$ \\
\hline Thickness at $3^{\circ} \mathrm{C}\left(\Delta z_{3^{\circ} \mathrm{C}}\right)$ & & $1.78(2)$ & $-0.69(4)$ & & \\
\hline Thickness at $1^{\circ} \mathrm{C}\left(\Delta z_{1}{ }^{\circ} \mathrm{C}\right)$ & $1.33(2)$ & & & & \\
\hline Core temperature $\left(T_{\min }\right)$ & $0.43(5)$ & $-0.99(4)$ & 0.38 & $-0.10(6)$ & $1.53(2)$ \\
\hline $\begin{array}{l}\text { Depth of the } T_{\min }\left(z_{T_{\min }}\right) \\
\text { Mean salinity }\left(S_{\mathrm{CIL}}\right)\end{array}$ & $-1.19(3)$ & $-1.96(1)$ & $-0.18(6)$ & $-0.01(7)$ & $-1.42(3)$ \\
\hline \multicolumn{6}{|l|}{ Deep layer } \\
\hline Mean temperature $\left(T_{\mathrm{d}}\right)$ & $1.53(1)$ & & & $-5.18(2)$ & $1.09(7)$ \\
\hline Mean salinity $\left(S_{\mathrm{d}}\right)$ & $-0.83(4)$ & & & 5.89 (1) & $-1.33(5)$ \\
\hline
\end{tabular}

Table 4. Relative contribution of each significant environmental variable (standardized regional and interannual macrozooplankton assemblages defined by the multivariate analysis (NMDS). Values in parentheses indicate rank. Percentages of the intergroup variance explained by axes I and II for the LSLE and the NW GSL are given

Biological differences

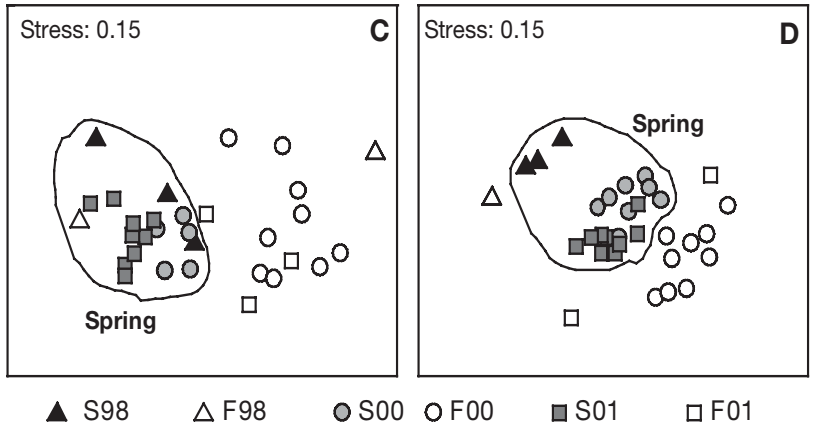

Fig. 6. Interannual analysis showing discrimination between years (98, 00 and 01) and seasons (S: spring; F: fall). (A) and (B) NMDS ordination based on the normalized Euclidean distance matrix derived from the mean of dimensionless physical parameters for the LSLE and NW GSL respectively. (C) and (D) NMDS ordination based on Bray-Curtis indices of similarity derived from log-transformed mean abundance of macrozooplankton species for the LSLE and NW GSL, respectively 
LSLE: $F_{(2,23)}=5.064 ; p=0.015$
NW GSL: $F_{(2,24)}=10.423 ; p<0.001$

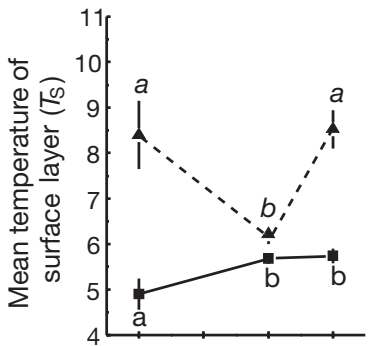

LSLE: $F_{(2,23)}=3.695 ; p=0.041$ NWGSL: $F_{(2,24)}=9.644 ; p<0.001$

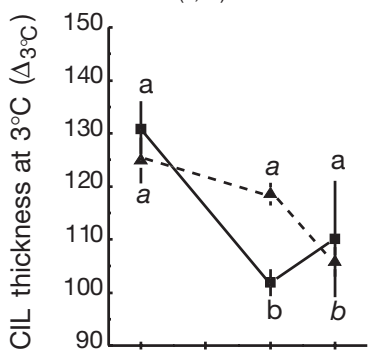

LSLE: $F_{(2,23)}=0.043 ; p=0.958$ NWGSL: $F_{(2,24)}=1.531 ; p=0.237$

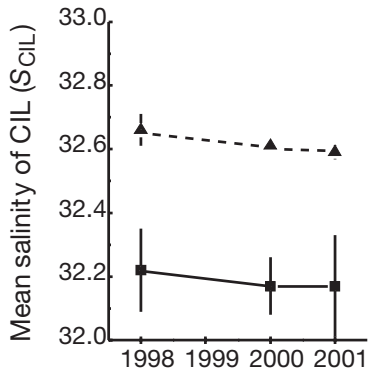

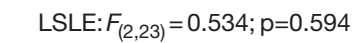

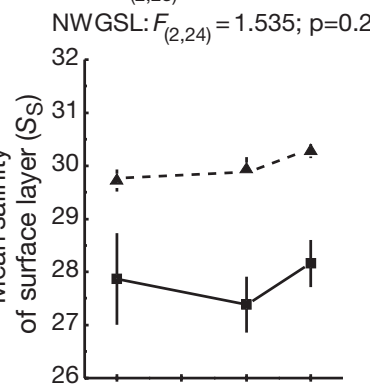

LSLE: $F_{(2,23)}=7.113 ; p=0.004$ NWGSL: $F_{(2,24)}=8.843 ; p<0.001$

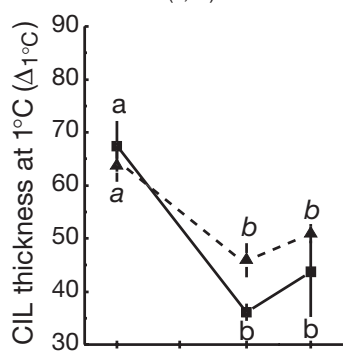

LSLE: $F_{(2,23)}=1.170 ; p=0.193$ NW GSL: $F_{(2,24)}=0.968 ; p=0.393$

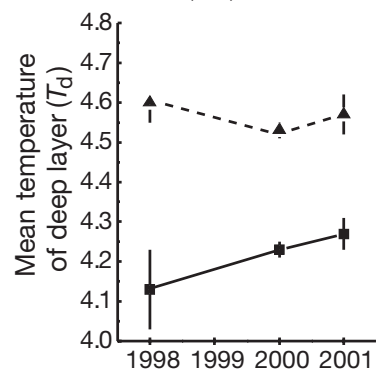

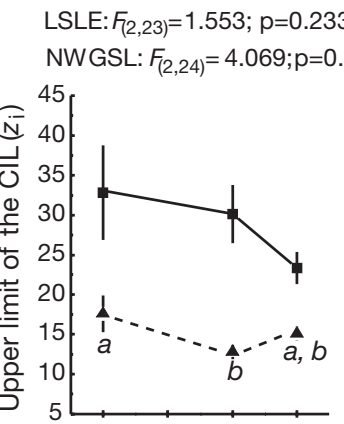

LSLE: $F_{(2,23)}=9.700 ; p=0.001$ NWGSL: $F_{(2,24)}=14.427 ; p<0.001$

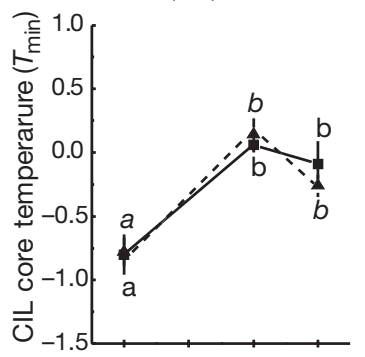

LSLE: $F_{(2,23)}=0.282 ; \mathrm{p}=0.757$ NWGSL: $F_{2,24)}=2.841 ; \mathrm{p}=0.078$

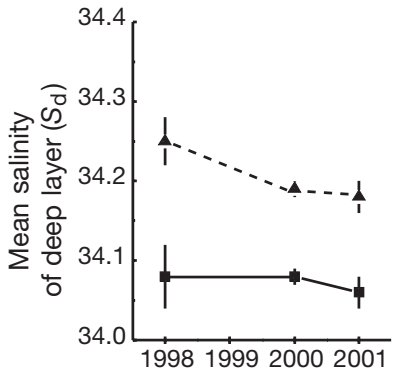

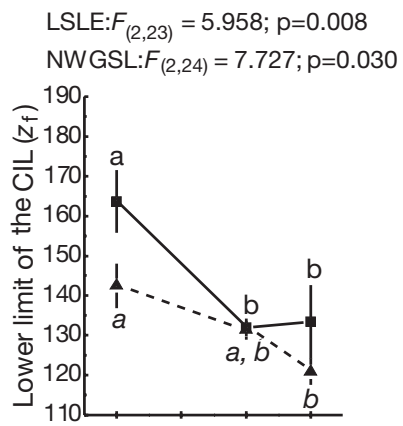

LSLE: $F_{(2,23)}=0.212 ; p=0.810$ NWGSL: $F_{(2,24)}=0.331 ; p=0.722$

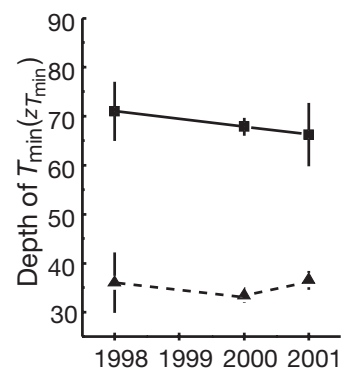

\section{Sampling year}

Fig. 7. Mean $( \pm \mathrm{SE})$ of physical parameters for each year measured in the LSLE (- - $)$ and NW GSL (-- $\mathbf{-}--)$, and results of 1-way ANOVAs and multiple comparison Tukey tests. Different letters above or below symbols indicate significant differences. Units are as in Table 2

NMDS ordinations (Fig. 6) and ANOSIM tests showed that the environmental variables and macrozooplankton community structure varied significantly between each year in both the LSLE and the NW GSL. The first 2 functions of these discriminant analyses explained $100 \%$ of the intergroup variance in the LSLE (Wilks' $\lambda=0.064, \mathrm{p}<0.001$ ) and in the NW GSL (Wilks' $\lambda=$ $0.009, \mathrm{p}<0.001)$. It resulted in the proper a posteriori classification of 88 and $96 \%$ of the physical parameters in the LSLE and in the NW GSL, respectively. In the LSLE, the first axis differentiated 1998 from 2000 and 2001 while the second axis contributed to differentiating 2000 from 2001 (Fig. 10A). The first and the second axes explained 74 and $26 \%$ of the intergroup variances, respectively. In the NW GSL, the first axis dif- ferentiated 1998 from 2001 while the second axis contributed to separating 2000 from the other years (Fig. 10 B). The first and second axes explained 52 and $48 \%$ of the intergroup variances, respectively. Six $\left(T_{\mathrm{S}}\right.$, $S_{\mathrm{S}}, Z_{\mathrm{i}}, \Delta z_{3^{\circ} \mathrm{C},}, T_{\min }$, and $\left.z_{T_{\min }}\right)$ and $7\left(T_{\mathrm{S}}, S_{\mathrm{S}}, \Delta z_{3^{\circ} \mathrm{C},} T_{\text {min }}\right.$ $z_{T_{\min }} T_{\mathrm{d}}$, and $S_{\mathrm{d}}$ ) main environmental variables separated the 3 groups observed in the LSLE and NW GSL, respectively (Table 4 ).

An examination of the environmental characteristics of each assemblage (Table 5) reveals that the macrozooplankton assemblage observed in the LSLE in 1998 was associated with a colder, thicker, and deeper CIL. Moreover, the CIL core temperature was deeper than the other years in this region. The surface layer was also colder in 1998 than in 2000 and 2001. On the other hand, 
Hyperiid amphipods

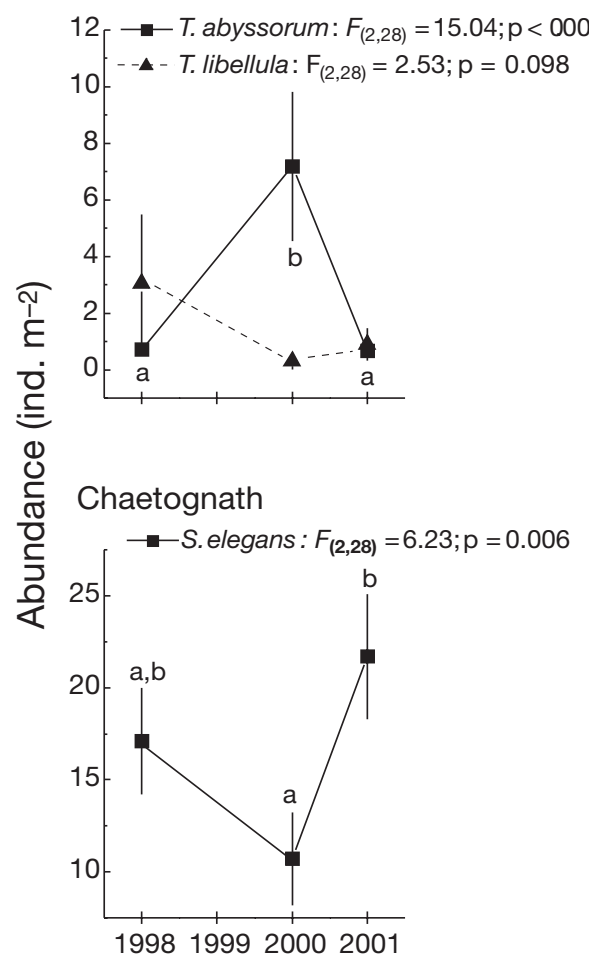

Hyperiid amphipods

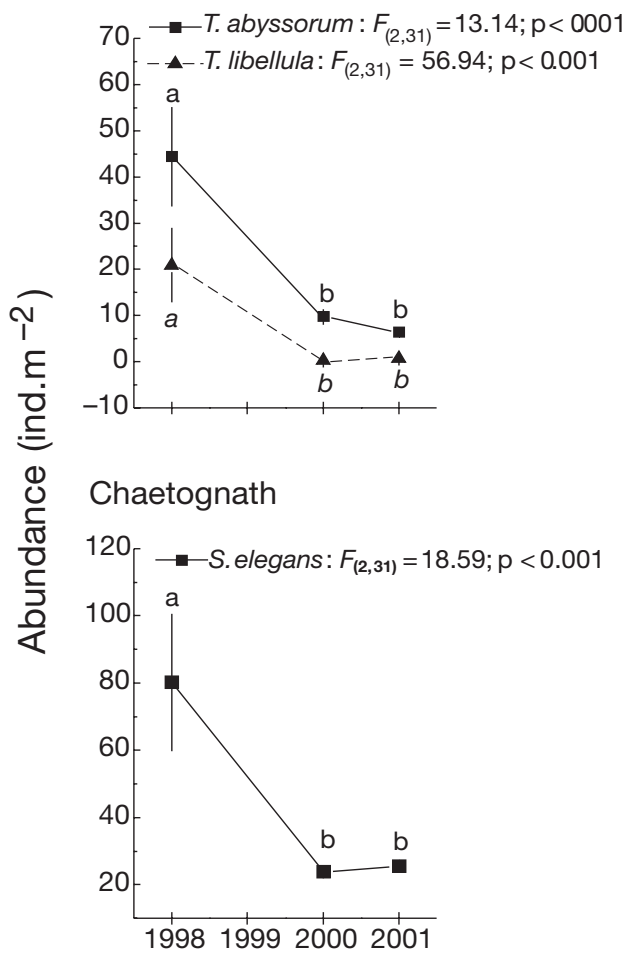

Euphausiids

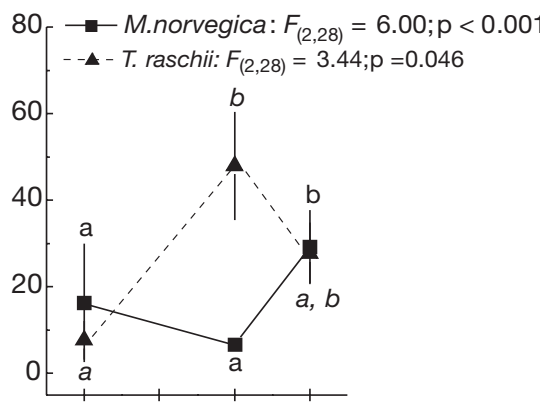

Hydromedusa/siphonophore

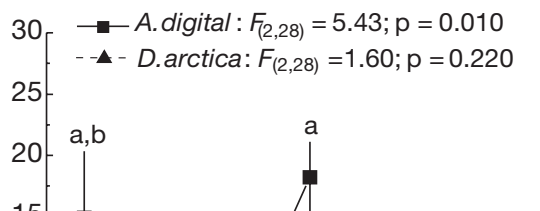

Mysid

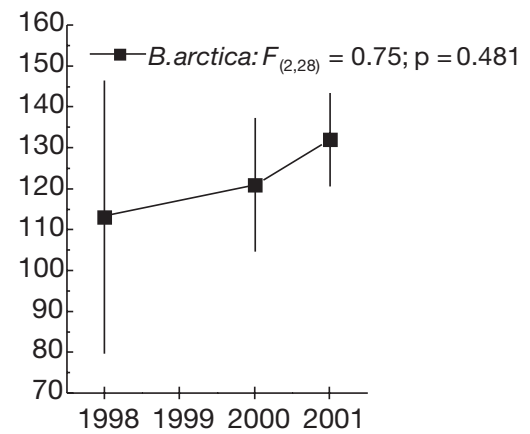

Fig. 8. Mean $( \pm \mathrm{SE})$ numerical abundances (ind. $\mathrm{m}^{-2}$ ) of macrozooplankton species measured in the LSLE in 1998, 2000, and 2001, and results of 1-way ANOVAs and multiple comparison Tukey tests. Different letters above or below symbols indicate significant differences

\section{Euphausiids}

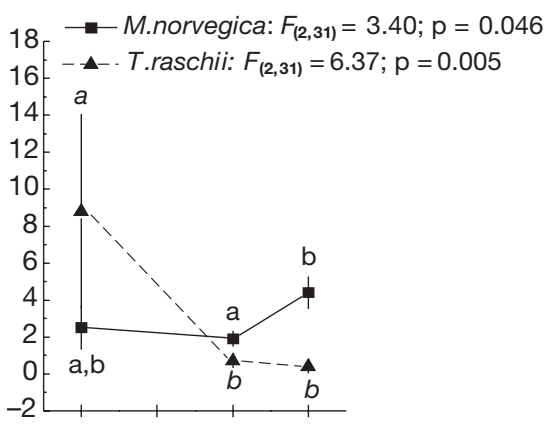

Hydromedusa/siphonophore

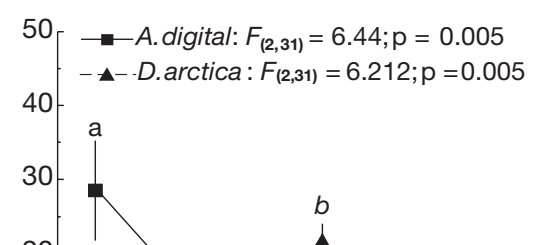

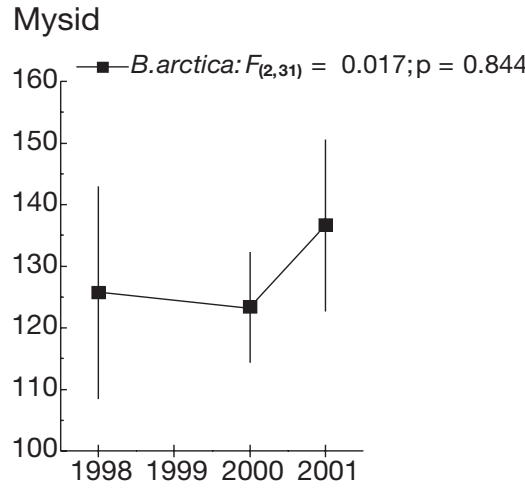

Fig. 9. Mean $( \pm \mathrm{SE})$ numerical abundances (ind. $\mathrm{m}^{-2}$ ) of macrozooplankton species measured in the NW GSL in 1998, 2000, and 2001, and results of 1-way ANOVAs and multiple comparison Tukey tests. Different letters above or below symbols indicate significant differences 

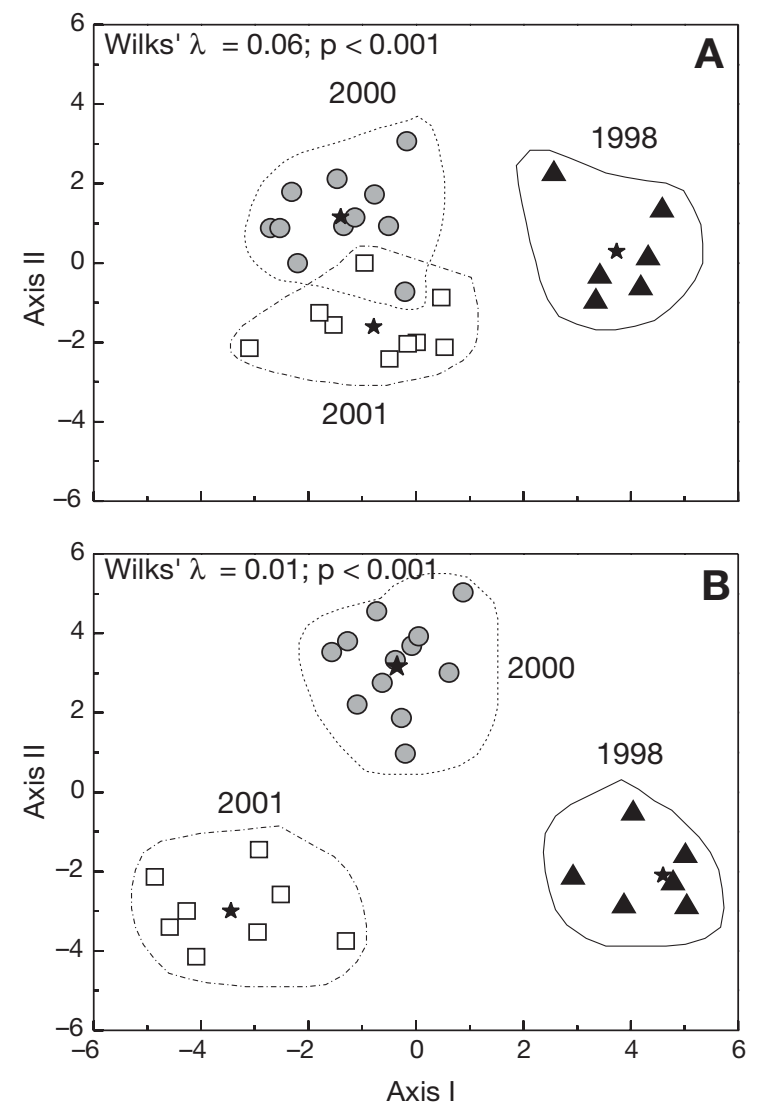

Fig. 10. Results of the discriminant analysis on the abundances of the principal macrozooplankton species in (A) LSLE and (B) NW GSL. The position of groups and their centroids ( $\star$ ) with respect to the first 2 discriminant axes are shown the year 2000 was characterized by a CIL that was warmer and thinner than in 1998 and 2001. The surface layer was also fresher in 2000 than in the other years in the LSLE. Finally, the surface layer in 2001 was saltier and warmer than in 1998 and 2000. The upper limit of the CIL and the CIL core temperature were also shallower in 2001 compared to the other years (Table 5).

In contrast, the CIL in the NW GSL in 1998 was colder and had a deeper lower limit than the other years. The surface was fresher and the deep layers were saltier than the other years. The deep layer was also warmer than in 2000 and 2001 in the NW GSL. In 2000, the CIL was warmer and had a core temperature shallower than in 1998 and 2001. The surface and deep layers were also colder in 2000 than in the other years in this region. Finally, 2001 had a warmer and saltier surface layer than in 1998 and 2000. The lower limit of the CIL was shallower and the CIL core temperature was deeper in 2001 than in the other years. The deep layer was fresher than for the other years in the NW GSL (Table 5).

\section{DISCUSSION}

\section{Regional variations}

Our results confirm that there was a regional difference between the LSLE (Sns K5 and O4) and the NW GSL (Stn U2) in both the physical parameters, and the macrozooplankton community structure and abun-

Table 5. Mean (SE) of physical parameters in LSLE and NW GSL. Variables that best discriminated groups of macrozooplankton taxa in each region are in bold

\begin{tabular}{|c|c|c|c|c|c|}
\hline Region & Layer & Physical parameter & 1998 & 2000 & 2001 \\
\hline \multirow[t]{3}{*}{ LSLE } & Surface layer & $\begin{array}{l}\text { Mean temperature }\left(T_{\mathrm{s}}\right) \\
\text { Mean salinity }\left(S_{\mathrm{s}}\right)\end{array}$ & $\begin{array}{r}4.90(0.34) \\
27.87(0.86)\end{array}$ & $\begin{array}{r}5.68(0.12) \\
27.38(0.53)\end{array}$ & $\begin{array}{r}5.74(0.16) \\
28.16(0.44)\end{array}$ \\
\hline & CIL & $\begin{array}{l}\text { Upper limit at } 3^{\circ} \mathrm{C}\left(z_{\mathrm{i}}\right) \\
\text { Lower limit at } 3^{\circ} \mathrm{C}\left(z_{\mathrm{f}}\right) \\
\text { Thickness at } 3^{\circ} \mathrm{C}\left(\Delta z_{3^{\circ} \mathrm{C}}\right) \\
\text { Thickness at } 1^{\circ} \mathrm{C}\left(\Delta z_{1^{\circ} \mathrm{C}}\right) \\
\text { Core temperature }\left(T_{\min }\right) \\
\text { Depth of the } \boldsymbol{T}_{\min }\left(z_{T_{\min }}\right) \\
\text { Mean salinity }\left(S_{\mathrm{CIL}}\right)\end{array}$ & 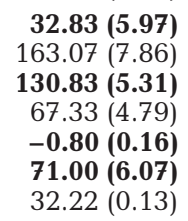 & $\begin{array}{r}\mathbf{3 0 . 1 1}(\mathbf{3 . 6 3 )} \\
131.99(2.26) \\
\mathbf{1 0 1 . 8 8}(\mathbf{2 . 5 6 )} \\
36.07(1.63) \\
\mathbf{0 . 0 6}(\mathbf{0 . 0 6 )} \\
\mathbf{6 7 . 8 6}(\mathbf{1 . 7 9 )} \\
32.17(0.09)\end{array}$ & $\begin{array}{c}\mathbf{2 3 . 3 3}(\mathbf{2 . 0 5 )} \\
133.40(9.27) \\
\mathbf{1 1 0 . 0 7}(\mathbf{1 0 . 9 6 )} \\
43.73(8.55) \\
\mathbf{- 0 . 0 9}(\mathbf{0 . 1 8 )} \\
\mathbf{6 6 . 2 2}(\mathbf{6 . 4 7 )} \\
32.17(0.16)\end{array}$ \\
\hline & Deep layer & $\begin{array}{l}\text { Mean temperature }\left(T_{\mathrm{d}}\right) \\
\text { Mean salinity }\left(S_{\mathrm{d}}\right)\end{array}$ & $\begin{array}{r}4.13(0.10) \\
34.08(0.04)\end{array}$ & $\begin{array}{r}4.23(0.02) \\
34.08(0.01)\end{array}$ & $\begin{array}{r}4.27(0.04) \\
34.06(0.02)\end{array}$ \\
\hline \multirow[t]{3}{*}{ NW GSL } & Surface layer & $\begin{array}{l}\text { Mean temperature }\left(T_{\mathrm{s}}\right) \\
\text { Mean salinity }\left(S_{\mathrm{s}}\right)\end{array}$ & $\begin{array}{r}8.40(0.75) \\
29.72(0.21)\end{array}$ & $\begin{array}{r}6.21(0.21) \\
29.93(0.23)\end{array}$ & $\begin{array}{r}8.52(0.42) \\
30.27(0.10)\end{array}$ \\
\hline & CIL & $\begin{array}{l}\text { Upper limit at } 3^{\circ} \mathrm{C}\left(z_{\mathrm{i}}\right) \\
\text { Lower limit at } 3^{\circ} \mathbf{C}\left(z_{\mathrm{i}}\right) \\
\text { Thickness at } 3^{\circ} \mathrm{C}\left(\Delta z_{3^{\circ} \mathrm{C}}\right) \\
\text { Thickness at } 1^{\circ} \mathrm{C}\left(\Delta z_{1^{\circ} \mathrm{C}}\right) \\
\text { Core temperature }\left(\boldsymbol{T}_{\min }\right) \\
\text { Depth of the } \boldsymbol{T}_{\min }\left(z_{T_{\min }}\right) \\
\text { Mean salinity }\left(S_{\mathrm{CIL}}\right)\end{array}$ & $\begin{array}{r}17.57(2.31) \\
\mathbf{1 4 2 . 4 3} \mathbf{( 5 . 6 2 )} \\
124.86(4.31) \\
63.71(3.01) \\
\mathbf{- 0 . 7 8}(\mathbf{0 . 1 1}) \\
\mathbf{3 6 . 0 0 ( 6 . 1 1 )} \\
32.66(0.05)\end{array}$ & $\begin{array}{r}12.76(0.59) \\
\mathbf{1 3 1 . 3 2}(\mathbf{2 . 4 1 )} \\
118.56(2.13) \\
45.90(3.20) \\
\mathbf{0 . 1 4}(\mathbf{0 . 1 3 )} \\
\mathbf{3 3 . 4 1}(\mathbf{1 . 3 8 )} \\
32.61(0.02)\end{array}$ & $\begin{array}{r}15.10(0.81) \\
\mathbf{1 2 0 . 8 8}(\mathbf{3 . 2 7}) \\
105.78(2.80) \\
50.93(1.85) \\
\mathbf{- 0 . 2 6}(\mathbf{0 . 0 9 )} \\
\mathbf{3 6 . 5 3}(\mathbf{1 . 9 4 )} \\
32.59(0.02)\end{array}$ \\
\hline & Deep layer & $\begin{array}{l}\text { Mean temperature }\left(T_{\mathrm{d}}\right) \\
\text { Mean salinity }\left(S_{\mathrm{d}}\right)\end{array}$ & $\begin{array}{r}4.60(0.05) \\
34.25(0.03)\end{array}$ & $\begin{array}{r}4.53(0.02) \\
34.19(0.01)\end{array}$ & $\begin{array}{r}4.57(0.05) \\
34.18(0.02)\end{array}$ \\
\hline
\end{tabular}


dance. The reasons for these differences are most likely related to the different circulation patterns. The LSLE is known to have a typical 2-layer estuarine circulation pattern, at least when laterally averaged. The surface downstream current is driven by freshwater runoff from the St. Lawrence River and its tributaries (Sutcliff et al. 1976, Koutitonsky \& Bugden 1991). This fresh-water discharge explains the less saline surface layer measured in this region compared to the NW GSL. Below this surface layer, there is a residual upstream displacement of deep water. The deep layer below the CIL is mainly formed by the mixing of deep Slope Water (North Atlantic) and Labrador Current Water at the margin of the continental shelf and advected into the LC (McLellan 1957, Lauzier \& Trites 1958, El-Sabh 1973, Bugden 1991). The tidal current in the LSLE encounters the sudden rise in the seabed at the head of the LC, forcing the upwelling and mixing of deeper waters (Forrester 1964, Steven 1974, Ingram 1975, Therriault \& Lacroix 1976). This explains why the surface layer of the LSLE is colder and more nutrientenriched than in the NW GSL (Gagnon 1997, Galbraith et al. 2002). The CIL is warmer and thinner in the LSLE than in the NW GSL. This is likely due to the advection of CIL waters from the NW GSL towards the LSLE by the estuarine circulation, combined with the erosion of the advected CIL layer (Ingram 1979). In contrast, the NW GSL is characterized by the presence of a quasipermanent cyclonic gyre (Trites 1972, El-Sabh 1976). The upward doming of colder water due to this anticlockwise rotation leads to a colder, thicker, and shallower CIL in the NW GSL than in the LSLE (ElSabh 1976).

The most abundant macrozooplankton species sampled in the LSLE and the NW GSL in spring and fall 1998, 2000, and 2001 was the mysid Boreomysis arctica. The abundance of $B$. arctica did not vary significantly between the sampled areas (LSLE and NW GSL) or between years or seasons in either area. The reason for this absence of variability in the species abundance is probably because $B$. arctica only occurs in the deep layer, between 150 and $300 \mathrm{~m}$, during both day and night in the LSLE and the NW GSL (M. Harvey unpubl. data). The high level of stability of this environment in terms of circulation pattern, temperature, and salinity (Lauzier \& Trites 1958, Ingram 1979) could explain the low variability in abundance of $B$. arctica in the LSLE and the NW GSL in spring and fall 1998, 2000, and 2001.

In contrast, for the other macrozooplankton species, which live mostly in the deep layer, the CIL, and/or the surface layer during the day and/or the night (M. Harvey unpubl. data), we found 2 distinct faunal groups that characterized the LSLE and the NW GSL: the LSLE had a higher abundance of 2 euphausiid species,
Meganyctiphanes norvegica and Thysanoessa raschii; the NW GSL had a greater abundance of the large carnivorous macrozooplankton species Sagitta elegans, Themisto abyssorum, Themisto libellula, and Dimophyes arctica. The euphausiids $M$. norvegica and $T$. raschii were 6 and 15 times more abundant in the LSLE than in the NW GSL, respectively. On the other hand, S. elegans, T. abyssorum, T. libellula, and D. arctica were twice as abundant in the NW GSL than in the LSLE. Runge \& Simard (1990) proposed that the observed spatial distribution of euphausiid aggregations in the LSLE results from the upstream advection in the LC of deep water containing adult euphausiids M. norvegica and T. raschii. On the other hand, young stages produced by these individuals would be transported into the GSL, perhaps in the vicinity of the Magdalena Shallows, by the downstream surface current along the southern side of the estuary and via the Gaspé Current (Runge \& Simard 1990).

In addition to the different circulation patterns, phytoplankton production can also influence the different community structures observed in the LSLE and the NW GSL. Indeed, the high freshwater discharge in spring and early summer in the LSLE and the spatiotemporal heterogeneity and hydrographic conditions are responsible for the different timing and intensity of phytoplankton blooms observed in the 2 regions (Sévigny et al. 1979, Therriault \& Levasseur 1985, de Lafontaine et al. 1991, Levasseur et al. 1992, Fuentes-Yaco et al. $1997 \mathrm{a}, \mathrm{b})$.

The LSLE is a nutrient-rich zone. The high freshwater discharge in spring and early summer generally delays the onset of the spring phytoplankton bloom until June (Therriault \& Levasseur 1985, Zakardjian et al. 2000). Afterwards, the upwelling and mixing of nutrient-rich cold water at the head of the LC maintains low temperatures and supports successive phytoplankton blooms during summer (Therriault \& Levasseur 1985, de Lafontaine et al. 1991, Koutitonsky \& Bugden 1991). These successive phytoplankton blooms should provide a favourable environment for euphausiids species, which are primarily herbivorous (Thysanoessa raschii) and omnivorous (Meganyctiphanes norvegica) (Sameoto 1976, Bamstedt 1988, Simard 1996).

In contrast, the NW GSL is characterized by a higher abundance of the large carnivorous macrozooplankton species. The Anticosti Gyre (AG) environment, like any other gyre environment, is relatively homogenous and stable (Sévigny et al. 1979, de Lafontaine et al. 1991). The NW GSL is characterized by a strong early spring phytoplankton bloom followed by nutrient-limited conditions over the summer months (Sévigny et al. 1979, Levasseur et al. 1992). Small flagellate phytoplankton species and a few species of large zooplankton (Calanusspp., euphausiids, chaetognaths, and 
shrimp) also characterize the NW GSL in summer (Sévigny et al. 1979, de Lafontaine et al. 1991, Roy et al. 2000).

The accumulation and/or the retention of large zooplankton species, in particular hyperiid amphipods, chaetognaths, and jellyfish, in gyres and/or eddies environments have already been reported in several studies. Mutlu \& Bingel (1999) and Mutlu (1999, 2001) have shown that the spatio-temporal horizontal distribution of some jellyfish species is related to the general current circulation in the Black Sea with higher concentrations in the center (Mnemiopsis leidyi) and the periphery (Aurelia aurita, Pleurobranchia pileus) of anticyclonic gyres. Lobel \& Robinson (1988) observed higher densities of fish larvae, hyperiid amphipods, gastropods, bivalve larvae, and chaetognaths in the central part of a cyclonic eddy in Hawaiian waters. Haury (1976) found more chaetognaths and polychaete larvae in the north Pacific central gyre than in the California Current. Pinca \& Dallot (1995) observed a higher concentration of large zooplankton species in the central part of the cyclonic Ligurian Current in the northwestern Mediterranean Sea. Therefore, the higher abundance of large carnivorous macrozooplankton species in the central AG is likely related to the general current circulation, which would favor the accumulation and/or the retention of these species within the gyre.

The higher abundance of carnivorous species in the NW GSL may also partly be explained by the higher abundance of large copepod species (Calanus spp.) present in the AG (de Lafontaine et al. 1991). These copepods would provide a good quantity quality of food to sustain various populations of large carnivorous macrozooplankton species.

\section{Interannual variations}

Important interannual variations in the abundance of the main macrozooplankton species were observed in 1998, 2000, and 2001 in the LSLE and NW GSL. This biological variability coincides with a significant interannual variability of the surface and CIL thermal properties, in particular in the NW GSL. In fact, the CIL was colder, thicker, and deeper in 1998 than in 2000 and 2001 in both regions. At the same time, in the NW GSL, the arctic (Thysanoessa raschii, Themisto libellula, and Aglantha digitalis) and boreo-arctic (Sagitta elegans and T. abyssorum) (Richard \& Haedrich 1991, Percy 1993, Dalpadado et al. 1998, 2001) macrozooplankton species were 5 times more abundant in 1998 than in 2000 and 2001. In contrast, the abundance of the more temperate species Meganyctiphanes norvegica (Dalpadado et al. 1998), did not vary significantly between 1998, 2000, and 2001.
The situation is different in the LSLE. There, we did not observe any relationship between the interannual variability in abundance of the various macrozooplankton species and their origin (arctic, boreo-arctic, or temperate), and the interannual variations of the CIL thermal properties or other physical parameters. The abundance of most of the arctic and boreo-arctic species in the LSLE was lowest in 1998 and highest in 2000 and/or 2001. To try to explain the interannual variations in the abundance of the macrozooplankton species in the LSLE, we again refer to the circulation pattern. The sharp CIL structure found during summer in the LSLE is not formed in situ but is advected there from the GSL (Ingram 1979). Saucier et al. (2003) examined the annual cycle of water masses and seaice in the GSL using a 3-dimensional coastal ocean model with realistic tidal, atmospheric, hydrologic, and oceanic forcing. They showed that in November 1997 in the LSLE, ca. 30 to $40 \%$ of the waters found in the CIL between 50 and $100 \mathrm{~m}$ originated from the Labrador Shelf, having transited there since the previous winter. Likewise, winter hydrographic measurements made each year in the GSL since 1996 showed large interannual differences in the salinity and temperature characteristics of the water masses in the GSL during winter (Starr et al. 2002). Indeed, some of the cold waters observed in the northeastern GSL in wintertime are too saline (32.35) to be formed locally and must come from outside this region, namely from the Labrador Shelf with advection into the GSL via the Strait of Belle Isle. This winter inflow is partly driven by large scale atmospheric forcing that causes a sealevel difference between opposite ends of the Strait of Belle-Isle (Garrett \& Petrie 1981). In 1998, 2000, and 2001, respectively, 444, 230, and $1314 \mathrm{~km}^{3}$ of waters were colder than $-1{ }^{\circ} \mathrm{C}$ and had a salinity greater than 32.35, and must have originated from the Labrador Shelf (P. Galbraith unpubl. data). Therefore, the higher abundance of arctic and boreo-arctic organisms observed in the LSLE in 2001 and the slightly lesser abundance observed in 1998 may coincide with the higher inflow of Labrador Shelf waters observed during these years. We can thus hypothesize that a higher inflow of Labrador Shelf waters into the GSL contributes to increasing the advection of macrozooplankton organisms into the LSLE, and that more abundance should be found in the fall than in the spring to account for the advection time to reach the LSLE. Future work will examine this hypothesis. On the other hand, the abundance of arctic and boreo-arctic species in the AG are correlated with local CIL conditions and retention mechanisms may be at work to accumulate and maintain the population. Data from longer time series (1994 to 2003) will be examined in the near future to confirm or refute this hypothesis. 
Acknowledgements. We thank J.-F. St-Pierre, P. Joly, and J.-P. Allard for their participation in the zooplankton sampling, and L. Devine for helping to improve the quality of the text. Our sincere thanks go to Drs. D. Mackas, S. Plourde and 4 anonymous reviewers for their comments, which were very helpful in revising the paper. This study is a contribution to the research program on Assessment of Climate Impact on Macrozooplankton (ACIM) of the Maurice Lamontagne Institute and was supported by the Canadian Department of Fisheries and Oceans.

\section{LITERATURE CITED}

Bamstedt U (1988) The macrozooplankton community of Kosterfjorden, western Sweden. Abundance, biomass, and preliminary data on the life cycles of dominant species. Sarsia 73:107-124

Bamstedt U (1998) Trophodynamics of Pleurobranchia pilens (Ctenophora, Cydippida) and ctenophore summer occurence off the Norwegian North-West coast. Sarsia 83: 169-181

Banks RE (1966) The cold layer in the Gulf of St. Lawrence. J Geophys Res 71:1603-1610

Berkes F (1976) Ecology of Euphausiids in the Gulf of St. Lawrence. J Fish Res Board Can 33:1894-1905

Berkes F (1977) Production of the euphausiid crustacean Thysanoessa raschii in the Gulf of St. Lawrence. J Fish Res Board Can 34:443-446

Bjerkan P (1919) The hydrodynamics of the Canadian Atlantic Waters. In: Hjort J (ed) Canadian fisheries expedition 1914-1915. Dept Naval Service, Ottawa, p 349-404

Bray JR, Curtis JT (1957) An ordination of the upland forest communities of southern Wisconsin. Ecol Monogr 27: 325-349

Brunel P, Bossé L, Lamarche G (1998) Catalogue of the marine invertebrates of the estuary and the Gulf of St. Lawrence. Can Spec Publ Fish Aquat Sci 126

Bugden GL (1991) Changes in the temperature-salinity characteristics of the deeper waters of the Gulf of St. Lawrence over the past several decades. In: Therriault JC (ed) The Gulf of St. Lawrence: small ocean or big estuary? Can Spec Publ Fish Aquat Sci 113:139-147

Chapman MG, Underwood AJ (1999) Ecological patterns in multivariate assemblages: information and interpretation of negative values in ANOSIM tests. Mar Ecol Prog Ser 180:257-265

Clarke KR, Ainsworth M (1993) A method of linking multivariate community structure to environmental variables. Mar Ecol Prog Ser 92:205-219

Clarke KR, Gorley RN (2001) PRIMER v5: User Manual/Tutorial. PRIMER-E: Plymouth

Clarke KR, Green RH (1988) Statistical design and analysis for a 'biological effects' study. Mar Ecol Prog Ser 46: 213-226

Clarke KR, Warwick RM (2001) Change in marine communities: an approach to statistical analysis and interpretation, 2nd edn. PRIMER-E: Plymouth

Dalpadado P, Ellertsen B, Melle W, Skjoldal HR (1998) Summer distribution patterns and biomass estimates of macrozooplankton and micronekton in the Nordic Seas. Sarsia 83:103-116

Dalpadado P, Borkner N, Bogstad B, Mehl S (2001) Distribution of Themisto (Amphipoda) spp. in the Barents Sea and predator-prey interactions. ICES J Mar Sci 58:876-895

de Lafontaine Y, Demers S, Runge J (1991) Pelagic food web interactions and productivity in the Gulf of St. Lawrence: a perspective. In: Therriault JC (ed) The Gulf of St. Lawrence: small ocean or big estuary? Can Spec Publ Fish Aquat Sci 113:99-123

Drinkwater KF, Colbourne E, Gilbert D (1999) Overview of environment conditions in the Northwest Atlantic in 1997. NAFO Sci Counc Stud 32:75-121

Drinkwater KF, Pettipas RG, Petrie WM (2000) An overview of meteorological and sea ice conditions off eastern Canada during 1999. DFO Can Stock Assess Sec Res Doc 2000/059. Department of Fisheries and Oceans Canada, Ottawa

El-Sabh MI (1973) Seasonal and long-term variations of the water properties in the Gulf of St. Lawrence. In: El-Sabh MI (ed) Proceedings of the Workshop of Physical Sciences in the Gulf and Estuary of St. Lawrence, Oct 11-12, 1973, Rimouski. University of Quebec, Rimouski, p 128-158

El-Sabh MI (1976) Surface circulation pattern in the Gulf of St. Lawrence. J Fish Res Board Can 33:124-138

El-Sabh MI (1979) The lower St. Lawrence estuary as a physical oceanographic system. Nat Can 106:55-73

Engelman L (2000) Discriminant analysis. In: Sytat 10 Statistic I. SPSS, Chicago, IL, p 275-326

Forrester WD (1964) A quantitative temperature-salinity study of the Gulf of St. Lawrence. Bedford Institute of Oceanography, report 64-11, Darmouth, NS

Fuentes-Yaco C, Vezina AF, Larouche P, Gratton Y, Gosselin M (1997a) Phytoplankton pigment in the Gulf of St. Lawrence, Canada, as determined by the Coastal Zone Color Scanner. Part II: multivariate analysis. Cont Shelf Res 17:1441-1459

Fuentes-Yaco C, Vezina AF, Larouche P, Vigneau C, Gosselin M, Levasseur M (1997b) Phytoplankton pigment in the Gulf of St. Lawrence, Canada, as determined by the Coastal Zone Color Scanner. Part I: spatio-temporal variability. Cont Shelf Res 17:1421-1439

Gagnon M (1997) Regional assessment - St. Lawrence lower estuary. Priority intervention zone 18. Environnement Canada, Quebec Region, Environmental Conservation, St. Lawrence Centre. St. Lawrence Centre of Environment Canada, Montreal

Galbraith PS, Saucier FJ, Michaud N, Lefaivre D, Corriveau R, Roy F, Pigeon R, Cantin S (2002) Shipborne monitoring of near-surface temperature and salinity in the Estuary and Gulf of St. Lawrence. In: Therriault JC, Devine L (eds) Atlantic zone monitoring program bulletin no. 2. Dept Fish Ocean Can, p. 26-30

Garrett C, Petri B (1981) Dynamical aspects of the flow through the Strait of Belle Isle. J Phys Oceanogr 11: 376-393

Gilbert D, Pettigrew B (1997) Interannual variability (19481994) of the CIL core temperature in the Gulf of St. Lawrence. Can J Fish Aquat Sci 54:57-67

Harvey M, St-Pierre JF, Joly P, Morrier G (2002) Oceanographic conditions in the Estuary and the Gulf of St. Lawrence during 2001: zooplankton. DFO Can Sci Advisory Sec Res Doc 2002/046. Department of Fisheries and Oceans Canada, Ottawa

Haury LR (1976) A comparison of zooplankton patterns in the California Current and North Pacific Central Grye. Mar Biol 37:159-167

Ingram RG (1975) Influence of tidal induced mixing on primary productivity in the St. Lawrence estuary. Mém Soc Roy Sci Liège 7:59-74

Ingram RG (1979) Water mass modification in the St. Lawrence estuary. Nat Can 106:45-54

Ingram RG, El-Sabh MI (1990) Fronts and mesoscale features in the St. Lawrence estuary. In: El-Sabh MI, Silverberg N 
(eds) Oceanography of a large-scale estuarine system: the St. Lawrence. Coast Estuar Stud 39:71-93

Koutitonsky VG, Bugden GL (1991) The physical oceanography of the Gulf of St. Lawrence: a review with emphasis on the synoptic variability of the motion. In: Therriault JC (ed) The Gulf of St. Lawrence: small ocean or big estuary? Can Spec Publ Fish Aquat Sci 113:57-90

Lauzier LM, Bailey WB (1957) Features of the deeper waters of the Gulf of St. Lawrence. Bull Fish Res Board Can 111: $213-250$

Lauzier LM, Trites RW (1958) The deep waters in the Laurentian Channel. J Fish Res Board Can 15:1247-1257

Lavoie D, Simard Y, Saucier FJ (2000) Aggregation and dispersion of krill at channel heads and shelf edges: the dynamics in the Saguenay - St. Lawrence Marine Park. Can J Fish Aquat Sci 57:1853-1869

Levasseur M, Fortier L, Therriault J, Harrisson P (1992) Phytoplankton dynamics in a coastal jet frontal region. Mar Ecol Prog Ser 86:283-295

Lobel PS, Robinson AR (1988) Larval fishes and zooplankton in a cyclonic eddy in Hawaiian waters. J Plankton Res 10: 1209-1223

Mackas D, Thomson R, Galbraith M (2001) Changes in the zooplankton community of the British Columbia continental margin, 1985-1999, and their covariation with oceanographic conditions. Can J Fish Aquat Sci 58:685-702

Marsden RF, Gratton Y (1998) Surface pulses in the Lower St. Lawrence Estuary. Atmos Ocean 36:271-295

McLellan HJ (1957) On the distinctness and origin of the Slope water off the Scotian Shelf and its easterly flow South of the Grand Banks. Fish Res Board Can 14: 213-239

Mutlu E (1999) Distribution and abundance of ctenophores and their zooplankton food in the Black Sea. 1l. Mnemiopsis leidyic. Mar Biol 135:603-613

Mutlu E (2001) Distribution and abundance of moon jellyfish (Aurelia auritia) and its zooplankton food in the Black Sea. Mar Biol 138:329-339

Multu E, Bingel F (1999) Distribution and abundance of ctenophores and their food in the Black Sea. I. Pleurobranchia pileus. Mar Biol 135:589-601

Percy JA (1993) Energy consumption and metabolism during starvation in the Arctic hyperiid amphipod Themisto libellula Mandt. Polar Biol 13:549-555

Pinca S, Dallot S (1995) Meso- and macrozooplankton composition patterns related to hydrodynamic structures in the Ligurian Sea (Trophos-2 experiment, April-June 1986). Mar Ecol Prog Ser 126:49-65

Plourde S, Runge JA (1993) Reproduction of the planktonic copepod Calanus finmarchicus in the lower St. Lawrence Estuary: relation to the cycle of phytoplankton production and evidence for a Calanus pump. Mar Ecol Prog Ser 102: $217-227$

Plourde S, Joly P, Runge JA, Zakardjian B, Dodson JJ (2001) Life cycle of Calanus finmarchicus in the lower St. Lawerence Estuary: the imprint of circulation and late timing of the spring phytoplankton bloom. Can J Fish Aquat Sci 58: $647-658$

Plourde S, Dodson JJ, Runge JA, Therriault JC (2002) Spatial and temporal variations in copepod community structure in the lower St. Lawrence Estuary, Canada. Mar Ecol Prog Ser 230:211-224

Plourde S, Joly P, Runge JA, Dodson JJ, Zakardjian B (2003) Life cycle of Calanus hyperboreus in the lower St. Lawrence Estuary and its relationship to local environmental conditions. Mar Ecol Prog Ser 255:219-233

Richard JM, Haedrich RL (1991) A comparison of the macro- zooplankton faunas in two Newfoundland fjords differing in physical oceanography. Sarsia 76:41-52

Roy S, Silverberg N, Romero N, Deibel D and 6 others (2000) Importance of mesozooplankton feeding for the downward flux of biogenic carbon in the Gulf of St. Lawrence (Canada). Deep-Sea Res II 47:519-544

Runge JA, Simard Y (1990) Zooplankton of the St. Lawrence estuary: the imprint of physical processes on its composition and distribution. In: El-Sabh MI, Silverberg N (eds) Oceanography of a large-scale estuarine system: the St. Lawrence, Vol 39. Springer-Verlag, New York, p 296-320

Runge JA, Castonguay $M$, De Lafontaine $Y$, Ringuette $M$, Beaulieu JL (1999) Covariation in climate, zooplankton biomass and mackerel recruitment in the southern Gulf of St Lawrence. Fish Oceanogr 8:139-149

Sainte-Marie B, Gilbert D (1998) Possible effects of changes in CIL temperature and thickness on population dynamics of snow crab, Chionoecetes opilio, in the Gulf of St. Lawrence. DFO, Can Stock Ass Sec Res Doc 98/38. Department of Fisheries and Oceans Canada, Ottawa

Sameoto DD (1976) Respiration rates, energy budgets, and molting frequencies of three species of euphausiids found in the Gulf of St. Lawrence. J Fish Board Can 33: $2568-2576$

Sameoto DD, Jarosynski LO, Fraser WB (1980) BIONESS, a new design in multiple net zooplankton samplers. Can J Fish Aquat Sci 37:722-724

Saucier FJ, Roy F, Gilbert D, Pellerin P, Ritchie H (2003) Modeling the formation and circulation processes of water masses and sea ice in the Gulf of St. Lawrence, Canada. J Geophys Res 108, No. C8, 3269 10.1029/2000 JC000686

Sévigny JM, Sinclair M, El-Sabh MI, Poulet S, Coote A (1979) Summer plankton distribution associated with the physical and nutrient properties of the Northwestern Gulf of St. Lawrence. J Fish Res Board Can 36:187-203

Simard Y (1996) Overview of the krill of the Gulf of St. Lawrence. Fisheries Centre Research Reports 3:53-57

Simard Y, Lavoie D (1999) The rich krill aggregation of the Saguenay St. Lawrence Marine Park: hydroacoustic and geostatistical biomass estimates, structure, variability, and significance for whales. Can J Fish Aquat Sci 56: 1182-1197

Simard Y, de Ladurantaye R, Therriault JC (1986a) Aggregation of euphausiids along a coastal shelf in an upwelling environment. Mar Ecol Prog Ser 32:203-215

Simard Y, Lacrois G, Legendre L (1986b) Diel vertical migrations and noctural feeding of a dense coastal krill scattering layer (Thysanoessa raschi and Meganyctiphanes norvegica) in stratified surface waters. Mar Biol 91:93-105

Starr M, Harvey M, Galbraith PS, Gilbert D, Chabot D, Therriault JC (2002) Recent intrusion of Labrador Shelf waters into the Gulf of St. Lawrence and its influence on the plankton community and higher trophic levels. 2002 ICES Annual Science Conference and ICES Centenary, Oct 1-5, 2002, Copenhagen 2002/N

Steven DM (1974) Primary and secondary production in the Gulf of St. Lawrence. Marine Sciences Center. Ms. Report No. 26. McGill University, Montreal

Sutcliff WHJ, Loucks RH, Drinkwater KF (1976) Coastal circulation and physical oceanography of the Scotian shelf and Gulf of Maine. J Fish Res Board Can 33:98-115

Tang CL (1980) Mixing and circulation in the northwestern Gulf of St. Lawrence: a study of a buoyancy-driven current system. J Geophys Res 85:2787-2796

Tee KT, Lim EH (1987) The freshwater pulse-a numerical model with application to the St. Lawrence estuary. J Mar Res 45:871-909 
Therriault JC, Lacroix G (1976) Nutrients, chlorophyll and internal tides in the St. Lawrence estuary. J Fish Res Board Can 33:2747-2757

Therriault JC, Levasseur M (1985) Control of phytoplankton production in the lower St. Lawrence Estuary: light and freshwater runoff. Nat Can 112:77-96

Trites RW (1972) The Gulf of St. Lawrence from a pollution point of view. In: Ruivo M (ed) Marine pollution and sea life. Fishing News, London, p 59-72

Editorial responsibility: Otto Kinne (Editor-in-Chief), Oldendorf/Luhe, Germany
Zakardjian B, Runge JA, Plourde S, Gratton Y (1999) A biophysical model of the interaction between vertical migration of crustacean zooplankton and circulation in the Lower St. Lawrence Estuary. Can J Fish Aquat Sci 56: $2420-2432$

Zakardjian BA, Gratton Y, Vézina AF (2000) Late spring phytoplankton bloom in the Lower St. Lawrence Estuary: the flushing hypothesis revisited. Mar Ecol Prog Ser 192: $31-48$

Submitted: October 25, 2004; Accepted: May 21, 2005 Proofs received from author(s): October 4, 2005 